Florida International University FIU Digital Commons

$11-24-2004$

\title{
The design, implementation and production process of creating a viable series of Latin shows in Hollywood, Florida
}

Cynthia Gredel Berrios

Florida International University

DOI: $10.25148 /$ etd.FI14051126

Follow this and additional works at: https://digitalcommons.fiu.edu/etd

Part of the Music Commons, and the Television Commons

\section{Recommended Citation}

Berrios, Cynthia Gredel, "The design, implementation and production process of creating a viable series of Latin shows in Hollywood, Florida" (2004). FIU Electronic Theses and Dissertations. 1711.

https://digitalcommons.fiu.edu/etd/1711 
FLORIDA INTERNATIONAL LNIVERSITY

Miami, Florida

THE DESIGN, IMPLEMENTATION AND PRODUCTION PROCESS

OF CREATING A VIABLE SERIES OF LATIN SHOWS

IN HOLL, YWOOD, FLORIDA

A thesis submitted in partial fultillment of the

requirements for the degree of

MASTER OF MUSIC

by

Cynthia Gredel Berrios

2004 
To: $\quad$ Dean R. Bruce Dunlap

College of Arts and Sciences

This thesis, written by Cynthia Gredel Berrios, and entitled The Design, Implementation and Production Process of Creating a Viable Series of Latin Shows in Hollywood, Florida, having been approved in respect to style and intellectual content, is referred to you for judgment.

We have read this thesis and recommend that it be approved.

Mark Nerenhausen

Fredrick Kaufman

Karen Fuller, Major Professor

Date of Defense: November 24, 2004

The thesis of Cynthia Gredel Berrios is approved.

Dean R. Bruce Dunlap

College of Arts and Sciences

Dean Douglas Wartzok

University Graduate School

Florida International University, 2004 


\section{DEDICATION}

I dedicate this thesis to my parents Mr. Cristobal Berrios and Mrs. Cynthia Berrios, thanks for all their support in every facet of my life. I also want to dedicate this thesis to my fiancé, Michael Calladine. Without your patience, understanding and support this work would not have been possible. Michael, you will continue to be my inspiration. We can finally be together. 


\section{ACKNOWLEDGMENTS}

I would like to acknowledge Professor Karen Fuller. Thanks for your support, patience and guidance. The Performing Arts Management Program was an essential key to my successful career. A special mention to Iasmarie Rodriguez and David Kauman for helping me with the graphic and costume design aspect of this project. 


\author{
ABTRACT OF THE THESIS \\ THE DESIGN, IMPLEMENTATION, AND PRODUCTION PROCESS OF \\ CREATING A VIABLE SERIES OF LATIN SHOWS IN HOLLYWOOD, FLORIDA \\ by \\ Cynthia Gredel Berrios
}

Florida International University, 2004

Miami, Florida

Professor Karen Fuller, Major Professor

The purpose of this research was to design and implement a Series of Latin Shows to be featured at the Satine Restaurant located in The Diplomat Hotel in Hollywood, Florida.

Three shows were created: "Electro Tango," "Bossa Nova Jazz," and "Piel Canela Night" to help generate interest for not only the Satine Restaurant but also for the surrounding area. The artistic concept included big bands, costumes, dancers and a DJ.

A production book was created and included the most important aspects of the individual shows such as budgets. costumes, and ground plans, to assure the success of each event. Careful analysis was done for the demographic area and a marketing plan was designed and implemented.

The research and practical application of similar shows in the industry determined that the production of these particular shows, although costly, have a qualifiable chance to succeed in this venue. 
I. INTRODUCTION 1

II. SELECTION OF THE VENUE 3

III. LET THE SHOWS BEGIN
A. Electro Tango
B. Bossa Nova Jazz
C. Piel Canela

IV. MARKETING

A. Marketing Demographic Study

B. Marketing Plan

V. PRODUCTION

A. Calendar

B. Meetings

C. Technical Rider

21

D. Master Cue Sheet

21

E. Ground Plan

21

F. Budget

VI. CONCLUSION

LIST OF REFERENCES 
Chapter I

\section{INTRODUCTION}

This thesis presents the development and production of a series of three Latin cross-cultural shows that will be performed at Satine restaurant at the Westin Diplomat Hotel located in Hollywood, Florida. Three cultures will be explored: Argentina, Brazil. and the Latino essence. The shows respectively are: "Electro Tango," "Bossa Nova Night." and "Piel Canela."

Although each show is unique in cultural content and artistic value, the shows are quite similar with respect to production value. These performances will bring back the live essence of each country and will include big bands, dancers, costumes, and a touch of modernism utilizing DJ's to make each night an unforgettable experience. The development and success of any production requires research, development, budgeting, rehearsal, and finally a marketing plan that will not only market to the target audience but also will help offset the marketing and production cost through corporate sponsorship.

For the research of these shows, each specific countries folk music, native costumes, and dance were studied for the choreography and development of each performance. After the initial research, each show has been designed with a detailed budget that includes costumes, performers, and equipment. Rehearsal schedules were then developed, ground plans drawn up, and detailed scene reports were written to assure each night's performance. Finally, a marketing strategy that will include email blast, direct mailings, corporate liquor sponsorships and promotions which will include a VIP kickoff party that will help target and bring the involvement of key city officials in the promotion of these shows. 
The City of Hollywood is achieving unprecedented growth in development over the past two years. The establishment of new hotels like The Westin Diplomat, play an important roll in city development. Located in what is considered North Miami, the City of Hollywood is in dire need of an identity to attract both tourist and local business to its economy as opposed to losing them to competing tourist- friendly alternatives such as nearby South Beach and Fort Lauderdale.

The arts and culture industry has proven to be one the fastest growing industries in Florida. Its annual statewide economic impact has grown from $\$ 1.7$ billion in 1997 to over $\$ 2.9$ billion according to a recent release by the Florida Cultural Alliance. Throughout Florida, arts and cultural resources are major components in the revitalization of communities, reforming schools, starting businesses, creating jobs and ultimately improving the quality of life for each community.

Beyond the natural beauty of white sand filled beaches, endless blue skies, ideal warm weather, restaurants, nightclubs and a distinctively Latin cultural influence are helping distinguish South Florida as one of the hottest destinations to visit. It is the intention of this research to show that combining all three into one (restaurant, nightclub, and Latin culture as a live interactive entertainment) will help create interest and boost the economy to an already developing area. 


\section{SELECTION OF THE VENUE}

Satine restaurant and lounge is located inside one of the largest tourist and local attractions in the Hollywood/ North Miami area. The Westin Diplomat Hotel has gained worldwide prestige with its unique designs and exotic locations throughout the world. The Diplomat Hotel attracts a high end, jet-setting clientele with an emphasis on corporate conventions. The hotel and the world-class restaurants and bars inside of it enjoy the benefits of near-capacity business almost year round. Not only that, but being a flagship and a critical darling in a developing area, with plenty of hotel parking inside, The Westin Diplomat Hotel has also attracted the locals ${ }^{\prime}$ interest who are happy to enjoy a night out right in their very own back yard.

Located in the main lobby and with a plethora of diners and curious guests on hand almost every night, Satine provides both the sufficient space and unique atmosphere that are necessary for this production. With a lounge/bar and dining area all combined in the same room with a great view of the stage, the restaurant layout allows great opportunities for this kind of a production.

Upon entering the room, the first impressions are low comfortable couches or ample cocktail tables dressed simply with regal glassware and soft candles that flicker and draw the guest's attention into the dimly lit room. Moving past smiling hosts with their reservations intact, the guest is approached and urged by cocktail waitresses in very attractive outfits to join them for a drink before retiring to their table for dinner and the show. The DJ has already started spinning records that suggest the culture that the guests and performers will be exploring for the evening. On the walls and on big screens, placed 
strategically throughout the room, alternating images of cultural icons will be projected with logos and advertisements of the nightly corporate sponsorship. The dining room lights have been kept low to create a sense of anticipation, guests will be moved to their tables followed by after dinner guests who will retire to the lounge area as the show is about to get started. 
Chapter III

\section{LET THE SHOWS BEGIN}

Frank Sinatra, Sammy Davis Jr. and Dean Martin have paved the way for the "dining experience." In fact, the same spot that Satine Restaurant is located is where the Rat Pack performed. The combination of magnificent voices, big bands and great performances gave a new meaning to dining out. Today, these shows prevail in Las Vegas where many choose to vacation for the gambling and also to enjoy the high profile celebrity shows while enjoying fine cuisine. The Palms and Hard Rock Café are just few examples of hotels that offer live shows in their locations in order to entertain their guest. The history of the "dinner show" really took off in Las Vegas and now is primed for a return. The Las Vegas style of entertainment and the Rat Pack, served as inspiration for the creation of the Series of Shows at Satine. With this in mind, let the shows begin.

\section{A. Electro Tango}

The seductive qualities of Tango will be felt as soon as the guest enters the room. One of the performers in native costume will be assisting the hosts in greeting the guests and giving the times of the three performances. A variety of projected images and promotions will suggest the night to come. Cocktail servers, bartenders, and dining room attendants will be suggesting beverages, such as Tango Tini’s, a special drink featuring the liquor company sponsorship of the evening.

Popular Argentinean hits and tango are spun by a house DJ located up in the center stage. The walls are covered with images, creating the glamorous ambiance of the 1920's. These images will include pictures of beautiful, tropical Argentina, local 
celebrities from tango history such as Carlos Gardel, and dashing romantic images of tango couples at play. As the last guests are ushered to their seats and the greeter is out in the lobby attracting new guests and announcing the show, the lights will be dimmed even lower and a spotlight will highlight the dancers and performers dressed in black and wearing set costumes. The band, with traditional players of local instruments such as the bandoneon, piano, bass and violin will start playing from their repertoire of classic and modern tango jazz.

As the lights are dimmed, the spotlights focus on a pair of dancers. They come from the dining room, and another pair comes from the cocktail area to meet on stage dancing to La Comparcita, one of the most famous and sexiest tango pieces. After La Comparcita, the dancers will dance to two more songs and then the lights go out on the dancers and shift focus back to the band that will begin their mesmerizing solos.

After the solos, voices are heard coming from the lobby area. The spotlights then focus on the door where two male tangueros are simulating a fight. The tangueros will jump on top of one of the dining tables to add more drama and tension to the scene. The fight slowly moves to the stage as a sexy female tanguera runs through the door finally getting to the stage. While the fight continues, the bassist is the only musician playing creating a very dramatic and intense mood. As soon as the female tanguera approaches the stage, the band starts playing in harmony with the bassist and the fight begins to flow to the choreography of the music. One of the tangueros finally gives up on the girl and proceeds to get another dancer that has stationed herself among the patrons at the bar.

Both couples dance dramatically and physically and then move off giving way to the DJ who will join the bandoneon player for the final set piece, which is the electric 
tango as three screens are brought onto the stage. Behind the screens, three sexy girls dressed as male dancers walk to the stage each grabbing a chair and as the music rises and builds they will do a partial striptease and reveal sexy outfits. The three dancers will then finally be joined with the other dancers who will move amongst the crowd and invite the guests to join them in dancing. Important: The dancers will remain and encourage guests to join them throughout the night after each performance as the DJ keeps the room exploding in a night of decadence and celebration.

\section{B. Bossa Nova Jazz}

Tonight the night is more like a carnival and the guest will be welcomed with Bossa Nova Jazz and Samba music being spun by a DJ. A Brazilian drink called carpirinas will be offered to the guest as they walk in the doors as a complimentary gift from corporate sponsors. A beautiful hostess in a traditional sexy carnival costume will also greet the guest and pass out a carnival bags. In the bags guest will find all the items needed to take part in the night's festivities. On the walls, images from Brazil. including carnivals, capoeira dancers, scantily clad women and important celebrities are projected.

A Bossa Nova band will open the show with sensual lyrics and classic Brazilian Jazz. The lights go down and spotlights focus on the main entrance and center stage. Three beriambau, two pandierios, one conga and one bell player (all musicians) will walk in through the main door to center stage. Following them, a group of six capoeristas dancers walk in from the backstage area singing. Musicians and performers meet center stage and interact with a series of jumps, kicks, flips, headstands and dance moves. 
Performers will move around the room in a celebratory fashion even including the occasional guests’ participation.

A DJ will take over playing Brazilian Tunes allowing the crew to get ready for the grand finale, the Carnival Parade. The parade starts with a sexy female carnival dancer who will enter from the back of the stage with a drummer and a whistle announcing the big carnival parade. She will do a dance and then walk around the restaurant until she disappears. Percussionists enter from the lobby and the back entrance. Leading the percussionists, dancers wearing authentic costumes, intriguing mask grass skirts and primitive clothes walk all over the room and will meet on stage to perform. As part of the performance, they will do acrobatics with sticks and machetes. This first group of performers now exit stage right, allowing Samba dancers to come to the stage as part of

the parade. Two percussionists will move on to the top of the bar. Female samba dancers will be wearing sexy, eye-popping and jaw-dropping costumes, while male capoeristas perform their acrobatic martial arts around them. The dancers will then split around the room. The percussionist will follow the dancers encouraging the guests to join the line of performers in a line dance that keeps building as the line between entertainers and audience becomes blurred.

\section{Piel Canela}

Upon entering the room guests' sensor will be assaulted with a fully swinging party already in motion. A DJ will be spinning recognizable and hip shaking hits from all over South America and the Caribbean. Scantily dressed dancers will be on the floor enjoying the various musical influences such as mambo, cha-cha-cha, salsa, bomba y 
plena and flamenco. Also adding a touch of modernism, musical fusion such as LatinJazz and European mixes with Latin swing will be featured as guests forget their own nationality finding themselves in one of the hottest parties in town. Bacardi brand images and famous Latin quotes will be projected on the walls and on screens and will also include images of famous celebrities from all over Latin America.

As the dancers finally exit, the DJ will stop and make way for a Latin jazz band to start performing. When the lights go all the way down, four pair of salsa dancers come out from both sides of the stage and perform a choreographed dance routine before giving way to the band again.

As part of the second performance, the salsa dancers will reappear and grab guests from the audience to be part of the show, maintaining the high energy in the room. Next, a single light will focus on the stage. Dancers will go back to their positions on stage to perform the last part of the set as the DJ begins spinning a familiar Gypsy King tune as a flamenco guitarist accompanies them until two flamenco dancers come out and perform along with two new guitarists. As part of the choreography the dancers will get on top of the bar and prop tables in the main dining room and lounge area until a complete black-out happens. as the lights are momentarily turned off all over the restaurant.

Next, a lone spotlight focuses on a trumpet player performing a haunting solo. Another spotlight then focuses on a percussionist that slowly begins accompanying the trumpet player. Five more pleneros and two congas (all percussionists), and six pair of dancers, all in Latin costumes will come from both sides of the stage. Performers will move around the room inviting people to become part of the festivities. The bar and 
tables suddenly become part of the stage. The dance floor will suddenly transform itself into a typical Puerto Rican carnival where bodies can't avoid dancing to the contagious rhythms. 


\section{MARKETING}

\section{A. Market Demographic Study}

The target market selection is one of the most important aspects of marketing. In order to develop a successful marketing plan, the first step is determining the target audience. In this specific study, the target market was based on age and income of the residents and travelers in the area. The next few paragraphs will show how and why the selected target audience will benefit from Satine's Series of Shows.

According to the City of Hollywood's general demographics, over $30 \%$ of the population ranges from $35-54$ years of age. Of this age group, the average household income is from $\$ 46,000$ - $\$ 54,000$. Based on these numbers and the overall success of other restaurants providing shows in the area it was determined that these target markets will be reached by creating the series of live entertainment shows hosted by Satine Restaurant.

Restaurants such as Taverna Opa in Hollywood, which offers an interactive experience of Greek music and dance, has been successfully captivating a local audience for years. Another popular restaurant in the area is Mai Tai, which offers the only Polynesian dance show in town. These are just two examples of two successful restaurants in the area that are already offering these types of shows.

Neighboring South Beach, primarily goes after a younger target audience. Restaurants and night clubs in that immediate area have focus their attention to catering to a more energetic crowd. Because of this, the Hollywood area is a perfect alternative for attracting an older demographic whose elub days are over but, that enjoy a more fulfilling 
dining out experience. The series of shows combining both dinner and show concepts are offering the option of the DJ after the show for those who want to stay and dance.

\section{B. Marketing Plan}

Like any other product. marketing these productions to a specific target audience is an essential part for the success of each show and production. The following marketing plan will focus on bringing the local and tourist guest to the restaurant each night, and in doing so will also include corporate sponsors and free advertising through local venues hoping to attract new guests to the area.

A press release will be created promoting the new International Nights at Satine in The Westin Diplomat Hotel in South Hollywood. Making the press aware of these new productions, they will be invited to a special VIP kickoff party along with many other local celebrities and influential guests in the immediate area. Corporate sponsors will donate the drinks and the restaurant will supply free appetizers as the guests will get a first time preview of each night's simulated performances.

The whole night promises to be like a cork blowing out of a champagne bottle that will be recorded for live spots on television and photo shoots that will be seen on various local magazines and television shows throughout the area. After the initial buzz has been created. we secure television spots advertising these shows. Direct mailings will also be sent out to over 15,000 households with an income of $\$ 50,000$ and over. The mailing piece will promote both Satine's menu and the International Nights productions. The first side of the mailer will promote the restaurant and will offer a complimentary 
bottle of wine or nightly drink specials from each corporate sponsor as part of buying dinner to see the show.

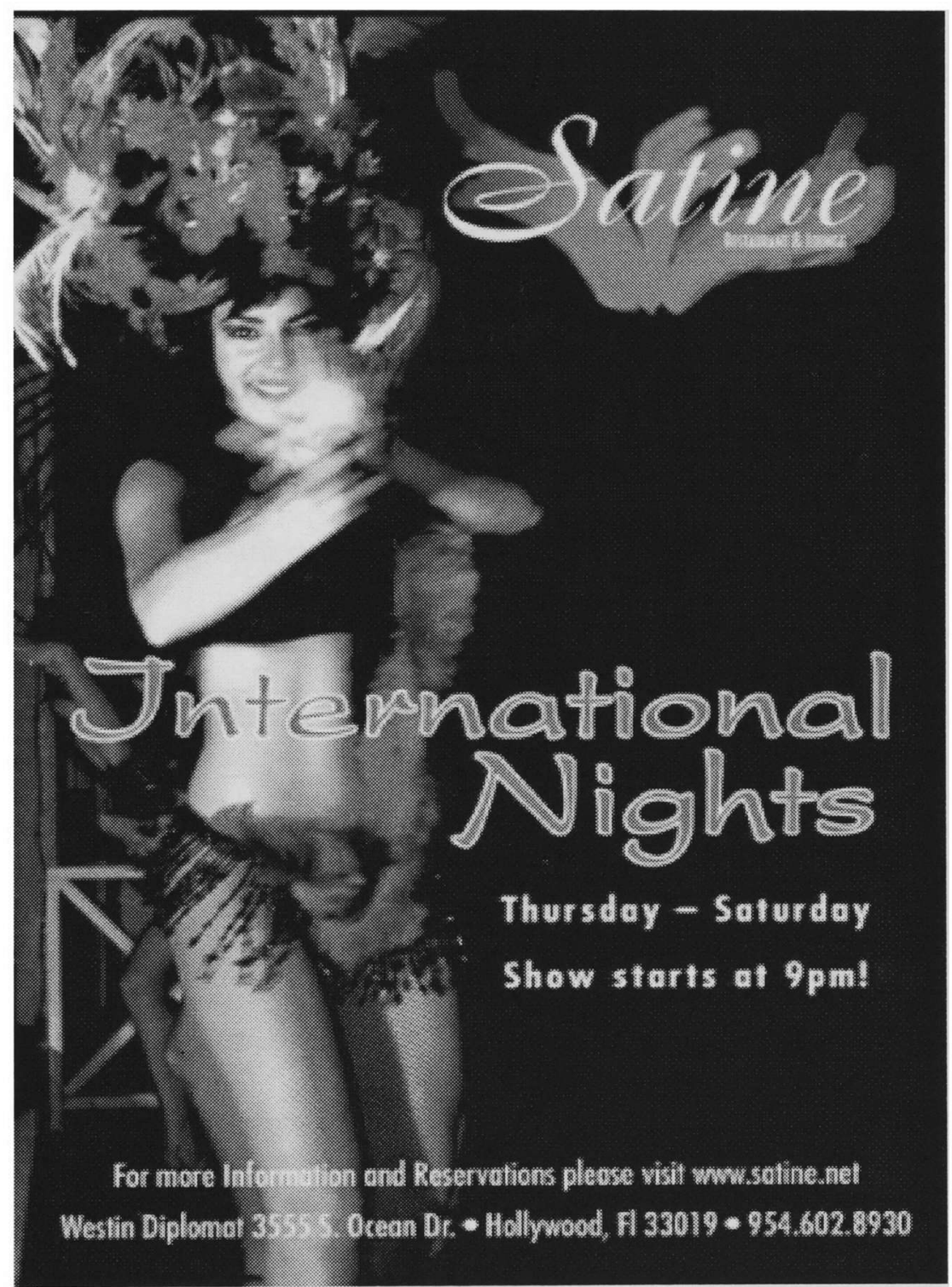

Figure 1. International Nights Mailer

The other side will promote the productions and have been done in color to accentuate the costumes and exotic skin tones of the performers. Corporate sponsorship pays for these mailings. 
In part with Satine"s already existing advertising budget, advertisements will be taken out in dining out sections of Florida newspapers including El Nuevo Herald. The Herald. New Times, Sun Times and Aventura Newspaper. The shows will also be advertised in magazines such as Aventura, Ocean Drive, and Las Olas Magazine.

One of the most powerful tools these days is the internet. Satine created an email blast for each night. This powerful tool allows the marketing team to send a reminder each night to their members list. Each night a sexy model will be utilized and designated to collect email addresses and contact information from the guests in the restaurant.

Satine also created a website with all the information regarding the restaurant and the events. The event page offers the viewers a fifteen second video clip of each night. The webpage includes upcoming events and any positive write-ups from the press. Every print media used will include the Satine's webpage address making the guest visit the page for more information.

Every month Satine will have an inaugural kickoff for each type of performance. On these parties the entertainment will include a famous celebrity that will be part of the show. These special events will benefit all the people on the VIP list and will offer them an exclusive privilege for being part of Satine's VIP list. This privilege will include invitation to private functions, special dinner promotions and a complimentary dinner for birthday celebration.

Flyers for each night were created and used as poster and table tents to promote each night. Valet parking will distribute the flyers to every car that valet parks at The Westin Diplomat Hotel. The poster will be located in front of the main doors of the restaurant in the lobby area. Table tents will be on every table in the restaurant. The same 
ad will also be placed in the informational video Janus Board of the hotel. (See in

Figures $2,3 \& 4$ )
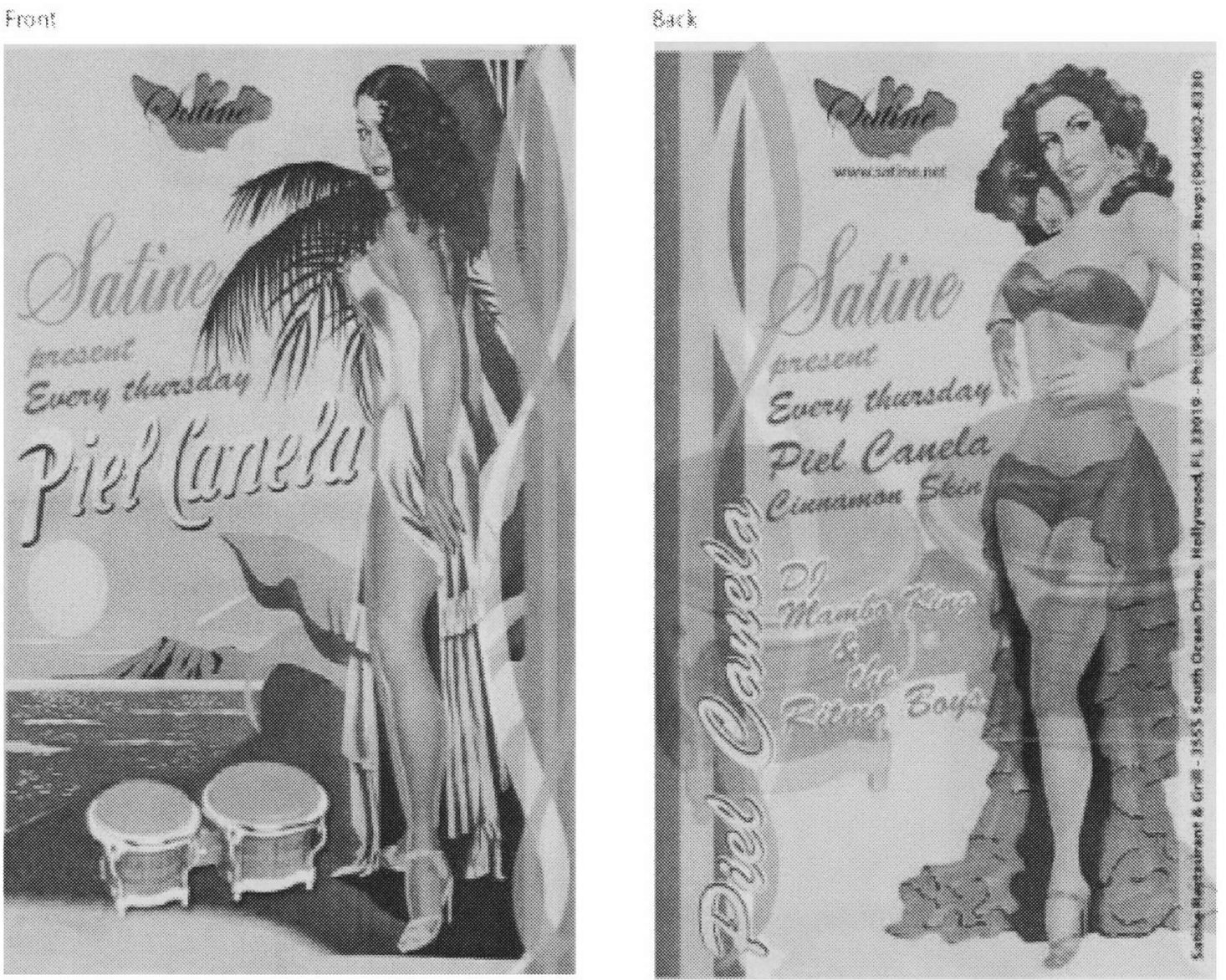

Figure 1. Piel Canela Night Flyer. 


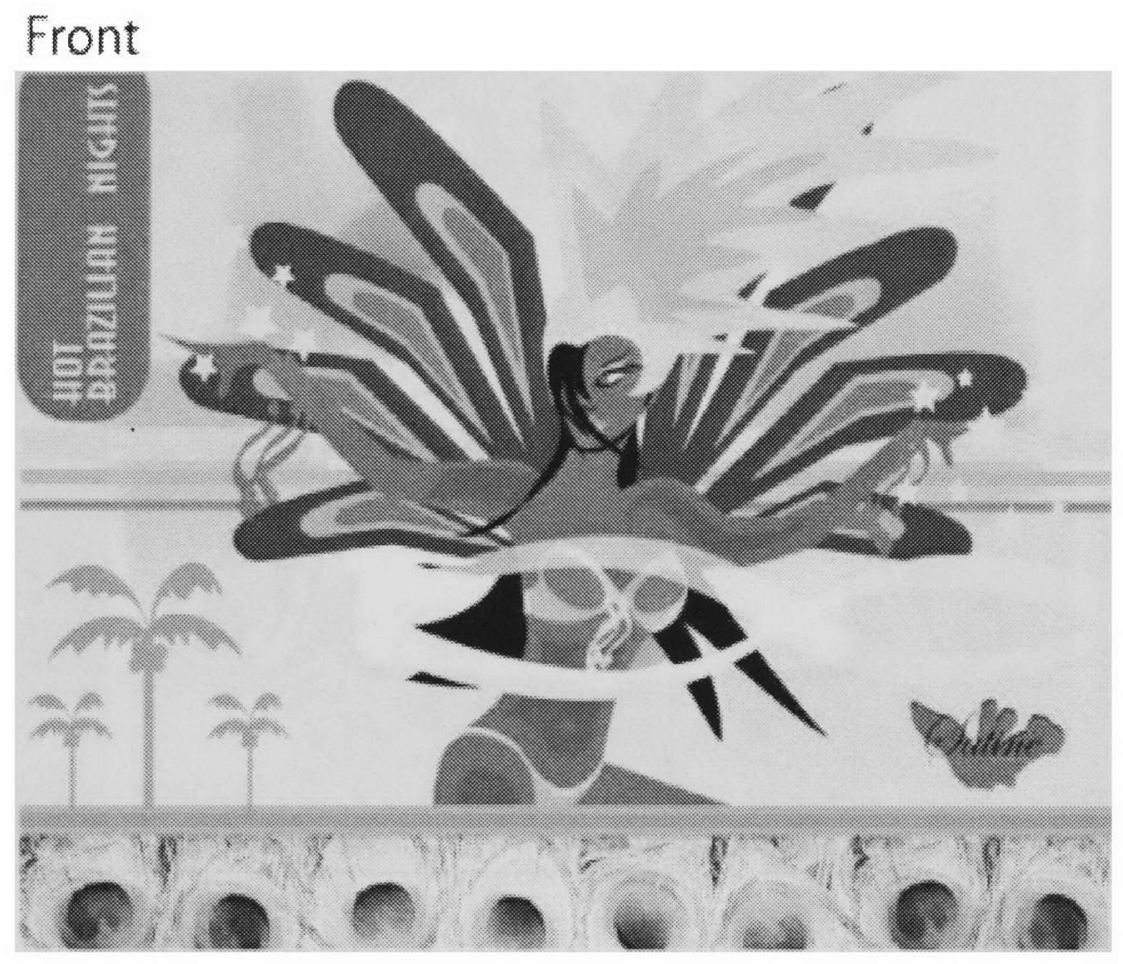

Back

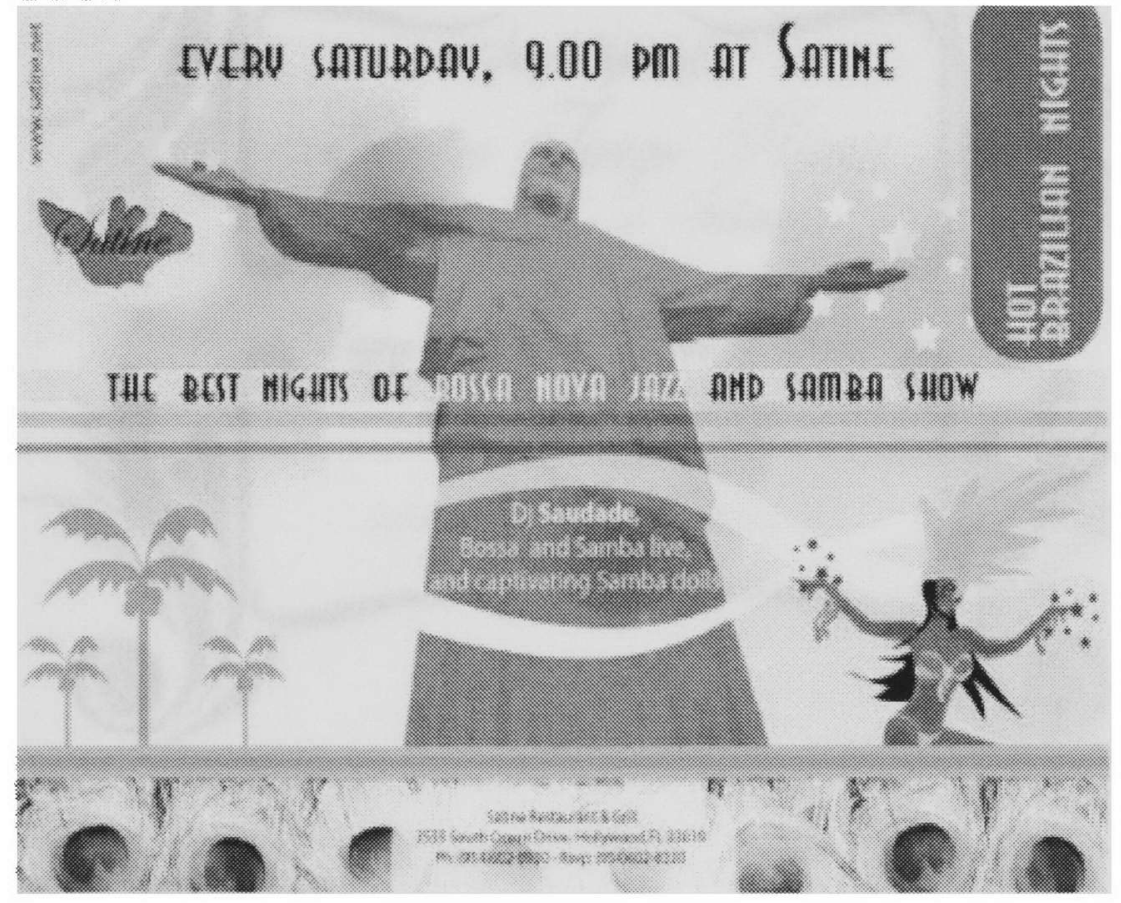

Figure 3. Bossa Nova Flyer. 

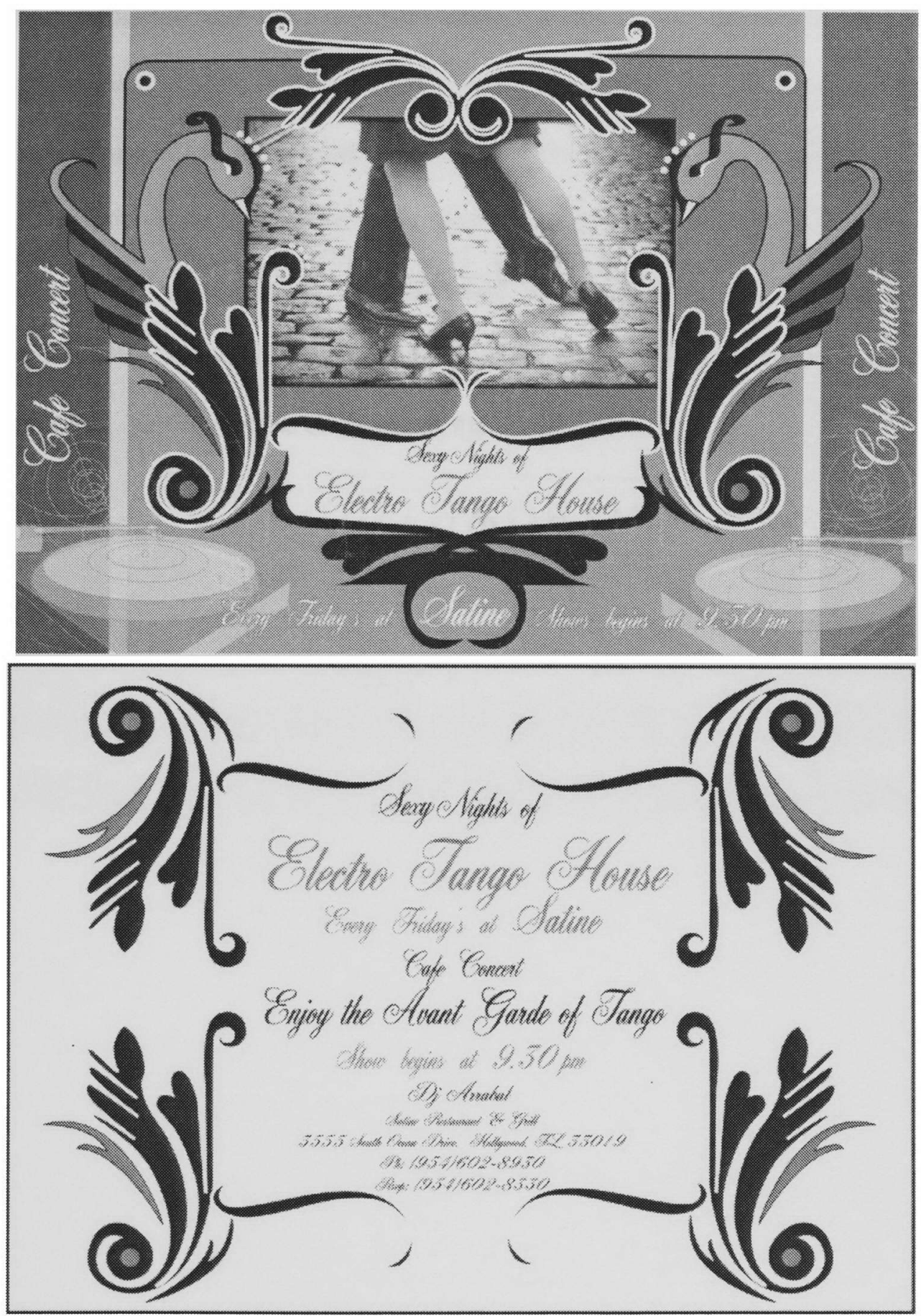

Figure 3. Electro Tango Flyer.

The critical aspects of this marketing plan are to find sponsorships to pay for the entertainment. Satine will offer a plan to liquor and wine companies where they can 
market their product to high-end customers through a unique sales approach. The goal is in a very Satine way, to invent a new form of direct marketing. The International Nights have the advantage of full interaction. live displays and usage by Satine staff or customers. As part of the deal Satine will also include the companies logos on all the advertisements. flyers, email blast and table tents. The logo will also be projected on the multimedia screen used on each show. Also added in the marketing kit is a promotional video clip, which showcases the elements of the all the shows. 
Table 1: $\quad$ Advertising Plan and Budget

\begin{tabular}{|c|c|c|c|c|}
\hline Printing & Description & Other & Cost & Total costs \\
\hline Poster & Design / Printing & One time & $\$ 600.00$ & $\$ \quad 600.00$ \\
\hline Flyers & Design/ Printing & One time & $\$ 300.00$ & 300.00 \\
\hline Janus Board & CD format & One time & $\$ 150.00$ & $\$ \quad 150.00$ \\
\hline Mailer & Design / Printing/ mailing & One time & $\$ 1,000.00$ & $\$ 1,000.00$ \\
\hline TOTAL & & & $\$ 2.050 .00$ & S. 2.050 .00 \\
\hline Advertising & Total ads & $\begin{array}{c}\text { Insertion } \\
\text { Size }\end{array}$ & Cost per ad & Total costs \\
\hline Aventura & 1 & $1 \mathrm{pg}$ color & $\$ 1,500.00$ & $\$ 1,500.00$ \\
\hline Las Olas Magazine & 2 & $1 \mathrm{pg}$ color & $\$ 2,200.00$ & $\$ 4,400.00$ \\
\hline Ocean Drive & 2 & $1 \mathrm{pg} \mathrm{color}$ & $\$ 3,000.00$ & $\$ 6,000.00$ \\
\hline El Herald & 2 & $1 / 2$ page & $\$ 500.00$ & $\$ 1,000.00$ \\
\hline New Times & 2 & $1 / 2$ page & $\$ 500.00$ & $\$ 1,000.00$ \\
\hline Dine Around & 3 & Full Page & $\$ 1,200.00$ & $\$ 3,600.00$ \\
\hline TOTAL PRINT: & 5 & & $\$ 6,700.00$ & $\$ 11.900 .00$ \\
\hline Webpage & & & Cost & Total costs \\
\hline Design Events Page & & One time & $\$ 700.00$ & $\$ 700.00$ \\
\hline Maintenance & Monthly & & $\$ 500.00$ & $\$ 500.00$ \\
\hline TOTAL PRINT & 10 & & $\$ 1,200.00$ & $\$ 1.200 .00$ \\
\hline \multicolumn{4}{|l|}{ TOTAL MEDIA PLAN } & $\$ 15.150 .00$ \\
\hline
\end{tabular}




\section{PRODUCTION}

After the development of the shows, the major component in any production is the production book. This book contains all the required data for each show including the production calendar, scene reports, technical rider, ground plans, rehearsals schedules and budgets.

\section{A. Calendar}

Keeping a production organized is an essential part for the success of any show. A production schedule is a detailed calendar specifying the date, time and location for the events to happen including auditions, rehearsals, production meetings, fittings and dress rehearsals among other things. It also helps the marketing team to schedule accordingly any interviews, photo shoots and press conferences for the shows. (See in Figure 5)

\section{B. Meetings}

The production meetings are held once a week to discuss the progress, changes in technical aspects and any concerns about the shows. These meetings are an important part of keeping everyone informed and making sure all the aspects of the production will fit well together. The Stage Manager mostly distributes the contact list, any design requirements and copies of the schedules and scene reports. A scene report states the time, set notes, costumes, props, sound and lighting info and the necessary performers and stage staff. Attached to it, there will be a ground plan showing all the necessary props and stage plots needed for the scene. After the meeting, the Stage Manager is responsible 
for updating the production book and handing out the changes before the rehearsals to the crew.

\section{Technical Rider}

A technical rider includes all the necessary elements for the shows in any specific venue. The information includes specific lighting system or fixtures, sound and stage specifications, music instruments and dressing rooms. The Stage Manager is in charge of putting it together with the production team and checking that the venue has everything that's required for the shows.

\section{Master Cue Sheet}

The master cue sheet is created for the Stage Manager to call the cues during the show. This is one of the most important tools of the show determining the flow of the performances. The master cue sheet includes all the lighting, sound and performer's entrance and exits to stage in chronological order. The cue sheet also includes the information and description of the cues.

\section{E. Ground Plan}

The ground plan is the diagram of the stage. Each scene will have a ground plan attached showing all the special props and specifics on the scenes. These ground plans are distributed to all the crew and production staff to ensure that each scene is set up properly. 
F. Budget

The budget is divided per show cost and other expenses. The three nights include the cost for the DJ, band. dancers, VJ projector, Spotlight Operator, costumes and the Stage Manager fees. The other expenses will include any additional expenses and technical equipment. It was intended to keep the cost of the shows at a moderate level without diminishing the quality of the shows in order to sell the series of shows to the restaurant. 


\section{CONCLUSION}

Developing a concept and show in a restaurant is enormously challenging and costly. It is a process that requires competent teams that are specialized in different areas. A dynamic and creative production team is needed to produce superior shows that exceed all expectations; also an innovative marketing plan, a defined target market and the use of all technological advances will help make the shows unique.

The production team has to carefully select the talent, music, costumes and choreographies along with creating detailed scene reports and floor plans for the creation of the shows. An extensive marketing plan that includes media coverage, email blasts, mailers, special parties and printed material has to be developed to inform people about the restaurant and the shows. Once the shows are developed and the marketing plan is completed, the show must go on.

After researching and developing these Series of Latin Shows for Satine restaurant this thesis concludes that there are many challenges and risks in developing and incorporating a Series of Latin Shows in a restaurant but there are many advantages to it. Incorporating the Series of Latin Shows in Satine restaurant will not only benefit the restaurant but also the Diplomat Hotel and the City of Hollywood by expanding the dining and entertainment alternatives for the locals and tourist. With the mixture of the Latin Series of Shows, fine dining and the ambient atmosphere, Satine will help place The Diplomat Hotel and the surrounding Hollywood area back on the map as it once was during the Rat Pack days. 


\section{LIST OF REFERENCES}

"A History of the Samba." Brazilianmusic.com. 2003. 6 July 2004. $<$ http:/www.brazilianmusic.com/samba.html $>$

Freedman, Harry, and Karen Feldman. The Business of Special Event. Florida: Pineapple Press, 1998.

Garcia, Ricardo. "La Comparcita." Todo Tango. 2004. 13 July 2004. $<$ http: www.todotango.com>

Gillette, J. Michael. Theatrical Design and Production: An Introduction to scene design and Construction, Lighting, Sound, Costume, and Makeup. $4^{\text {th }}$ ed. Mountain View: Mayfield Publishing Company, 2000.

Kotler, Philip, and Joanne Scheff. Standing Room Only: Strategies for Marketing the Performing Arts. Boston: Harvard Business School Press, 1997.

Romero, Bruno E. "Argentine Tango History." 1996. 24 June 2004.

$<$ http://www.cnetralhome.com/ballroomcountry/argentino_tango.htm>

Stern. Lawrence. Stage Management. $7^{\text {th }}$ ed. Boston: Allyn and Bacon, 2002.

"The Tango: A Way of Dance, A Culture, a Way of Life." ShowGate.1995. 26 March, 2004. <http://www.showgate.com/tango/history.html>

Viana. Isabel M. "What is Bossa Nova?" PageWise Home. 2002. 29 June 2004. $<$ http://ri.essortment.com/watisbossano_ribe.htm> 


\begin{tabular}{|c|c|c|c|c|c|c|}
\hline & & & & & $\begin{array}{l}1 \\
\text { Dancers Auditions } \\
12-4 \mathrm{pm} \\
\text { Satine Restaurant }\end{array}$ & $\begin{array}{l} \\
\text { Musicians } \\
\text { Auditions } \\
12-4 \mathrm{pm} \\
\text { Satine Restaurant }\end{array}$ \\
\hline 3 & $\begin{array}{l}4 \\
\text { Production } \\
\text { Meeting } \\
2 \text { 2-4pm/Call } \\
\text { Back } \\
\text { a Satine }\end{array}$ & $\begin{array}{l}5 \\
\text { Dancers Fitting } \\
12-4 \mathrm{pm} \\
\text { a Satine }\end{array}$ & $\begin{array}{l}6 \\
\text { Musicians Fitting } \\
12-4 \mathrm{pm} \\
\text { a Satine }\end{array}$ & 7 & 8 & 9 \\
\hline 10 & $\begin{array}{l}11 \\
\text { Production } \\
\text { Meeting } \\
2-4 \mathrm{pm}\end{array}$ & $\begin{array}{l}12 \\
\text { Electro Tango } \\
\text { Rehearsal/Photo } \\
\text { Shoot a Satine }\end{array}$ & $\begin{array}{l}13 \\
\text { Bossa Nova } \\
\text { Rehearsal } \\
\text { Photo Shoot } \\
\text { a Satine }\end{array}$ & $\begin{array}{l}14 \\
\text { Piel Canela } \\
\text { Rehearsal/ } \\
\text { Photo Shoot } \\
\text { di Satine }\end{array}$ & 15 & 16 \\
\hline 17 & $\begin{array}{l}18 \\
\text { Production } \\
\text { Meeting } \\
2-4 \mathrm{pm}\end{array}$ & $\begin{array}{l}19 \\
\text { Electro Tango } \\
\text { Rehearsal } \\
\text { á Satine }\end{array}$ & $\begin{array}{l}20 \\
\text { Bossa Nova } \\
\text { Rehearsal } \\
\text { a Satine }\end{array}$ & $\begin{array}{l}21 \\
\text { Piel Canela } \\
\text { Rehearsal } \\
\text { a Satine }\end{array}$ & 22 & 23 \\
\hline \begin{tabular}{|l}
24 \\
Production \\
Meeting \\
2 -4pm
\end{tabular} & $\begin{array}{l}25 \\
\text { Electro Tango } \\
\text { Rehearsal } \\
a \text { Satine }\end{array}$ & $\begin{array}{l}26 \\
\text { Bossa Nova } \\
\text { Rehearsal } \\
\text { a Satine }\end{array}$ & $\begin{array}{l}27 \\
\text { Piel Canela } \\
\text { Rehearsal } \\
\text { a Satine }\end{array}$ & $\begin{array}{l}28 \\
\text { DRESS } \\
\text { REHEARSAL } \\
a \text { Satine }\end{array}$ & $\begin{array}{l}29 \\
\text { Press } \\
\text { Conference } \\
\text { VIP Kickoff Party } \\
8 p m \text { Cocktails } \\
9 \text { pm Shows } \\
\text { a. Satine }\end{array}$ & $\begin{array}{l}30 \\
\text { Piel Canela Night }\end{array}$ \\
\hline $\begin{array}{l}31 \\
\text { Bossa Nova }\end{array}$ & & & & & & \\
\hline
\end{tabular}




\section{LATIN SERIES OF SHOWS \\ REHEARSAL SCHEDULE}

\begin{tabular}{|c|c|c|c|c|c|c|}
\hline Sunday: & Monday & Thestay & Wednesday & Thurstay & Friday & Sumuray \\
\hline Profuction & Electro Tango & Bossa Nova & Piel Canela & Dectro Tango & Bossa Nowa & Piel Canela \\
\hline Meeting & Rehearsal & Rehearsal & Reltearal & Performance & Performance & Performance \\
\hline \multirow[t]{6}{*}{$2-4 p m$} & $2-3 \mathrm{~mm}$ Band & $2-3 p m$ Band & $2.3 \mathrm{mmBand}$ Sadsa & All Grew $77 m$ & $4 I / \operatorname{Crov} 7 \mathrm{pm}$ & $4 / \mathrm{Crew} / 7 \mathrm{pm}$ \\
\hline & $3.33 \mathrm{~mm}$ BREAK & $6330 /$ Capoera & $3330 \mathrm{pm}$ Flamenco & 8.9pmBand & $9.10 \mathrm{pm} / \mathrm{Band}$ & Q-10.36minand \\
\hline & $330-434 \mathrm{pm} / \mathrm{Comparcta}$ & 3.3LHMWBREAK & $330 \mathrm{~mm}$ BREAK & 909 inm Compar & $10,30-11$ pm/Capo & $11-1130$ onmFlamenoo \\
\hline & $430-5 \mathrm{~mm}$ BREAK & $4-43 \mathrm{~mm}$ Cammal & 4.9.pm camial & $030.11330 \mathrm{~mm}$ Fight & $11 \mathrm{pm}-12 \mathrm{Cam}$ al & $11.45 \mathrm{pm}-12 \mathrm{am} / \mathrm{plena}$ \\
\hline & $5-5.30 \mathrm{PM}$ Fint & & & $10,34 \mathrm{~mm}-12 \mathrm{am} / \mathrm{Smp}$ & $12 a n d$ & \\
\hline & $5300 \mathrm{pm}$ Strntease & & & $12 \mathrm{amDI}$ & & \\
\hline
\end{tabular}




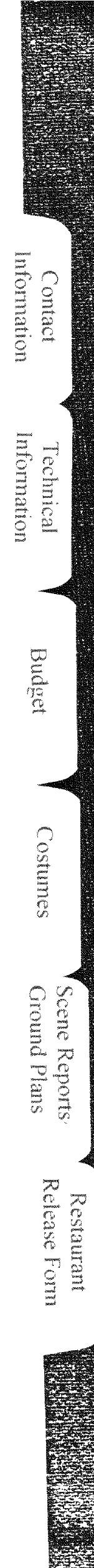




\section{CONTACT SHEET}

\begin{tabular}{|c|c|c|c|}
\hline Name & $\begin{array}{l}\text { Phone/ } \\
\text { Fax \# }\end{array}$ & Address & Notes \\
\hline Satine & $950-602-8930$ & $\begin{array}{l}3555 \text { S. Ocean Drive } \\
\text { Hollywood. FL } 33019\end{array}$ & Restaurant \\
\hline Anyela Gutierrez & $954-602-8930$ & $\begin{array}{l}3555 \text { S. Ocean Drive } \\
\text { Hollywood. FL } 33019\end{array}$ & Manager \\
\hline Gredel Berrios & $954-224-8346$ & & Producer/Stage Manager \\
\hline Ismarie Rodriguez & $954-602-1134$ & & Costume Designer \\
\hline Martika Gutierrez & $305-975-6059$ & $\begin{array}{l}880 \text { NE } 69 \text { th ST. APT. } 4 \mathrm{~m} \\
\text { Miami. FL } 33138\end{array}$ & Choreographer \\
\hline Thedra Taylor & $954-985-8777$ & $\begin{array}{l}1910 \text { Fillmore St. } 2 \\
\text { Hollywood, FL } 33020\end{array}$ & Dancer \\
\hline Jessica Norris & $954-261-1643$ & $\begin{array}{l}2121 \text { N. } 51 \text { Are } \\
\text { Hollywood. FL } 33021\end{array}$ & Dancer \\
\hline Name & No. & Address & Dancer \\
\hline Name & No. & Address & Dancer \\
\hline Name & No. & Address & Dancer \\
\hline Name & No. & Address & Dancer \\
\hline Armando Pena & $786-306-9779$ & $\begin{array}{l}441 \text { NW } 109 \text { Ave. } \\
\text { Miami. FL } 33172\end{array}$ & D.J \\
\hline Andrew & $305-984-2299$ & $\begin{array}{l}1923 \mathrm{SW} 23 \mathrm{St} \\
\text { Miami.FL } 33145\end{array}$ & D.J \\
\hline Freddy & $954-923-5565$ & $\begin{array}{l}1705 \text { Rodman St. } \\
\text { Hollywood. FL } 33021\end{array}$ & DJ \\
\hline Name & No. & Address & DJ \\
\hline Name & No. & Address & DJ \\
\hline Name & No. & Address & DJ \\
\hline Anthony Church & $951-849-8256$ & $\begin{array}{l}1200 \text { Charles Place Suite } \\
\text { Pembroke Pines. Fl } 33026\end{array}$ & Musician \\
\hline Reinel Rios & $954-761-3312$ & $\begin{array}{l}255 \text { Galen Key Biscayne } \\
\text { Miami. Fl } 33143\end{array}$ & Musician \\
\hline Cesar Abanato & $786-486-0969$ & $\begin{array}{l}2841 \text { SW } 26 \\
\text { Miami.FL } 33133\end{array}$ & Musician \\
\hline Name & No. & Address & Musician \\
\hline Name & No. & Address & Musician \\
\hline Name & No. & Address & Musicians \\
\hline Billy Berrios & $954-292-4676$ & Address & VJ Operator \\
\hline Name & No. & Address & VJ Operator \\
\hline Dan Causy & $954-602-8750$ & 3660 S. Ocean Drive & Light Operator \\
\hline
\end{tabular}




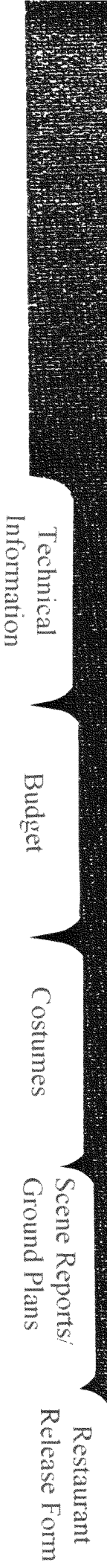




\section{TECHNICAL RYDER / SATINE SHOW SERIES}

Stage Dimension

- Platform Stage (wood) 18 Feet wide and 12 Feet Long.

Loading Dock

- One emergency Door in Back Stage Left. (9 Feet Long and 6 Feet Wide.)

\section{Lighting}

- 2 Electric Batten

- 2 spot lights

- 10 Parabolic aluminized reflector (PAR)

- 8 Ellipsoidal (ERS) reflector.

Sound

- DJ booth with:

2 techniques SL 1200 Turning tables

2 Denon Cd table player players

1 Rane MP knob Mixer

1 rane Cross fader/Ch EQ

1 Behringer live mixer board

2 Furman PL-plus Power Conditioners

2 A.Tech. Opera-Lyric 415 active Mon

2 Road Ready 18 Sapace Racks w/Wheels

Props

- Yamaha Piano 


\section{TECHNICAL CHECKLIST}

Show:

Check Time:

Stage Manager:

Technical Director:

Sound:

Sound System

Speakers

Mics

Monitors

Sound Board

Light:

Stage Lighting

Gels

Dimmer

Light Board

Stage

Dressing Rooms
Music Stand
Props




\section{SATINE SERIES OF SHOWS \\ MASTER CUE SHEET}

\begin{tabular}{|l|l|}
\hline $\begin{array}{l}\text { Show: } \\
\text { Date: }\end{array}$ & Tlectro Tango \\
Time: & $9: 00$ pm \\
Stage Manager: Gredel Berrios \\
\hline Cue\# & Description \\
\hline 1 & general wash \\
\hline 2 & Greeter \\
\hline 3 & VJ images ON \\
\hline 4 & DJ ON \\
\hline 5 & greeter out to lobby area \\
\hline 6 & lights down \\
\hline 7 & greeter to backstage \\
\hline 8 & first tangueros on stage \\
\hline 9 & spot light to follow tangueros \\
\hline 10 & band starts \\
\hline 11 & lights down \\
\hline 12 & scene 2 dancers /coming from dining room \\
\hline 13 & spot light to follow tangueros \\
\hline 14 & tangueroS on lobby area \\
\hline 15 & spot light to follow tangueros from lobby area \\
\hline 16 & band Q/La Comparcita \\
\hline 17 & lights out on dancers focus on band \\
\hline 18 & dancers exit \\
\hline 19 & band/ solos \\
\hline 20 & bandoneon solo \\
\hline 21 & lights out for band \\
\hline 22 & spot light on main entrance \\
\hline 23 & male dancers for tanguero fight ON \\
\hline 24 & female dancers ON \\
\hline 25 & band ON \\
\hline 26 & tanguero fight lighting pre-set \\
\hline 27 & DJ ON \\
\hline 28 & band/ dancers out \\
\hline 29 & props for strep tease \\
\hline 30 & pre-set for strep tease \\
\hline 31 & dancers scene $3 /$ striptease \\
\hline 32 & additional dancers striptease \\
\hline
\end{tabular}




\section{SATINE SERIES OF SHOWS \\ MASTER CUE SHEET}

\begin{tabular}{|l|l|}
\hline \multicolumn{1}{|l|}{ Show: } & Bossa Nova \\
Date: & Friday \\
Time: & $9: 00$ pm \\
Stage Manager: Gredel Berrios \\
\hline Cue\# & Description \\
\hline 1 & general wash \\
\hline 2 & DJ \\
\hline 3 & VJ images ON \\
\hline 4 & greeter carnival costume \\
\hline 5 & band general wash \\
\hline 6 & greeter out \\
\hline 7 & bossa nova jazz band ON \\
\hline 8 & lights down \\
\hline 9 & jazz band first set done \\
\hline 10 & spot light on main entrance and center stage \\
\hline 11 & Brazilian percussion / band center stage \\
\hline 12 & capoeristas center stage \\
\hline 13 & lights down on performers \\
\hline 14 & DJ / Brazilian tunes \\
\hline 15 & performers out \\
\hline 16 & carnival lighting pre-set \\
\hline 17 & carnival dancer \& drummer enter from back stage \\
\hline 18 & first group of percussionist to exit stage right \\
\hline 19 & samba dancers on stage \\
\hline & \\
\hline & \\
\hline & \\
\hline & \\
\hline & \\
\hline & \\
\hline & \\
\hline & \\
\hline
\end{tabular}




\section{SATINE SERIES OF SHOWS \\ MASTER CUE SHEET}

\begin{tabular}{|c|c|}
\hline $\begin{array}{l}\text { Show: } \\
\text { Date: } \\
\text { Time: } \\
\text { Stage M }\end{array}$ & $\begin{array}{l}\text { Piel Canela Night } \\
\text { Saturday } \\
\text { 9:00pm } \\
\text { anager: Gredel Berrios }\end{array}$ \\
\hline Cue\# & Description \\
\hline 1 & general wash \\
\hline 2 & VJ roll \\
\hline 3 & DJ \\
\hline 4 & Latin dancers on stage with DJ Q \\
\hline 5 & dancers exit \\
\hline 6 & ban on stage \\
\hline 7 & DJ -out \\
\hline 8 & band to perform \\
\hline 9 & lights on the band down \\
\hline 10 & lights focus on dancing floor \\
\hline 11 & salsa dancers \\
\hline 12 & salsa dancers exit \\
\hline 13 & lights out on band \\
\hline 14 & DJ to play Gypsy King tunes \\
\hline 15 & lights focus on two guitarists \\
\hline 16 & flamenco dancers come out \\
\hline 17 & Q light for flamenco dancers \\
\hline 18 & lights down \\
\hline 19 & flamenco dancers and guitarists to exit \\
\hline 20 & trumpet player on stage / solo \\
\hline 21 & spot light on trumpet pet player \\
\hline 22 & spot light focus on percussionist \\
\hline 23 & all dancers pleneros come from stage right \\
\hline & \\
\hline & \\
\hline & \\
\hline & \\
\hline & \\
\hline & \\
\hline
\end{tabular}




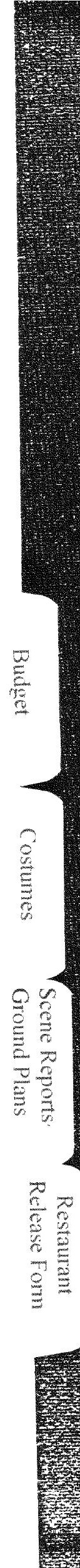




\section{SATINE SERIES OF SHOWS \\ BUDGET}

Thursday

Electro Tango

DJ

Band

Dancers / \$125 each

VJ Operator

Spot Light Operators

Costumes/One Time Fee

Stage Manager

Total
$\$ 250.00$

$\$ 600.00$

$\$ 625.00$

$\$ 100.00$

$\$ 150.00$

$\$ 800.00$

$\$ 200.00$

$\$ 2,725.00$

Friday

Bossa Nova Jazz

D.J

$\$ 250.00$

Band

$\$ 900.00$

Percussionists $\$ 100$ each

$\$ 700.00$

Dancers / \$125 each

$\$ 1.250 .00$

VJ Operator

$\$ 100.00$

$\$ 150.00$

Spot Light Operators

$\$ 800.00$

$\$ 200.00$

Stage Manager

$\$ 4,350.00$

Saturday

Piel Canela

D.J

$\$ 250.00$

Band

$\$ 900.00$

Misc. Percussion

$\$ 375.00$

Dancers / \$125 each

$\$ 1,000.00$

VJ Operator

$\$ 100.00$

Spot Light Operators

$\$ 150.00$

$\$ 800.00$

$\$ 200.00$

Stage Manager

Total

$\$ 3,775.00$

Other Expenses:

Projector/One Time Fee

$\$ 1,000.00$

Audio Visual Video/ One Time

Fee

$\$ 1,500.00$

Total

$\$ 13,350.00$ 


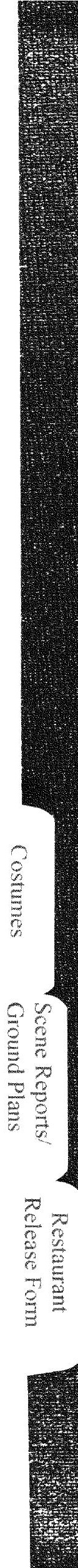


Electro Tango

Costume

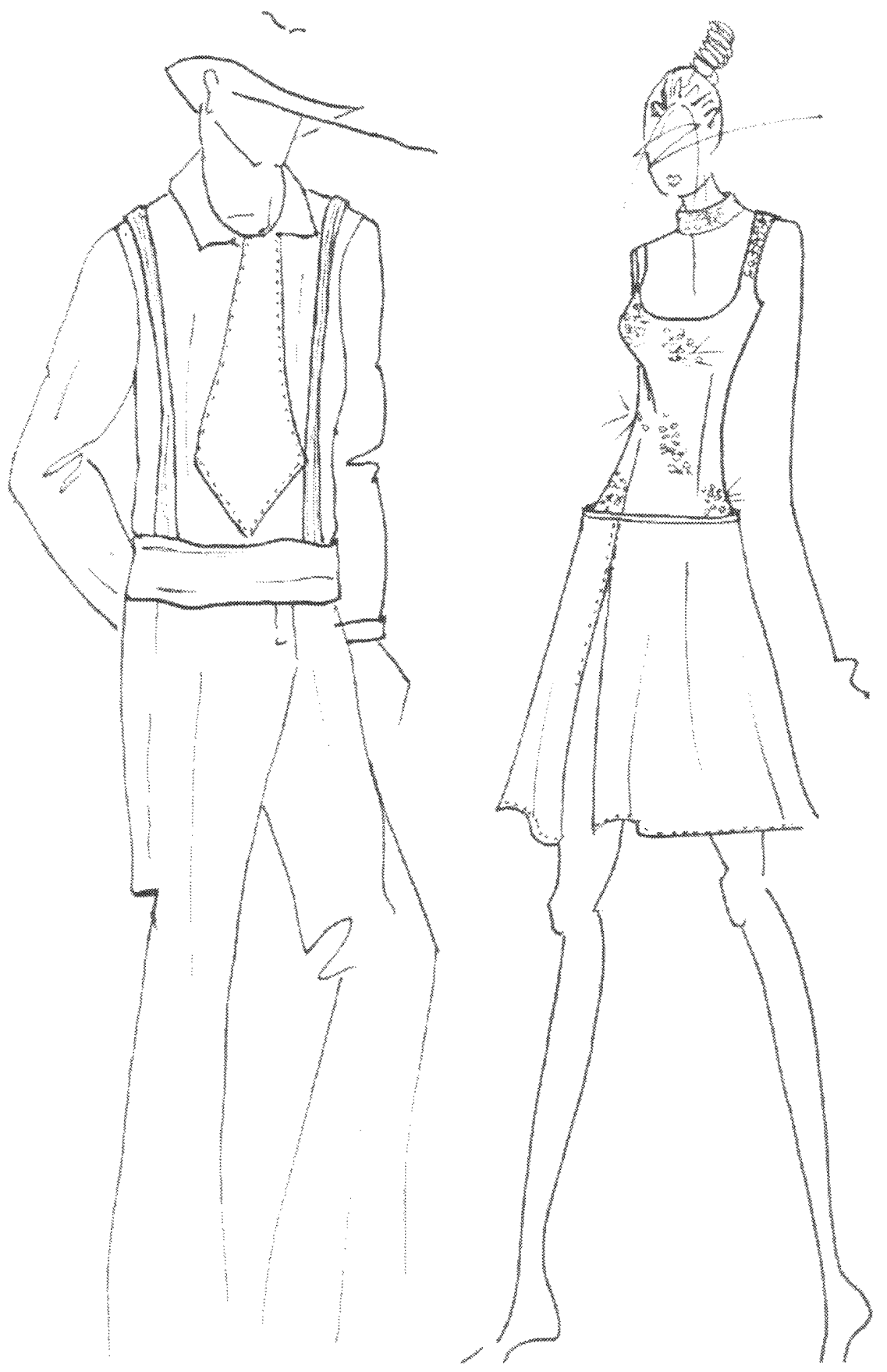




\section{Greeter Costume}

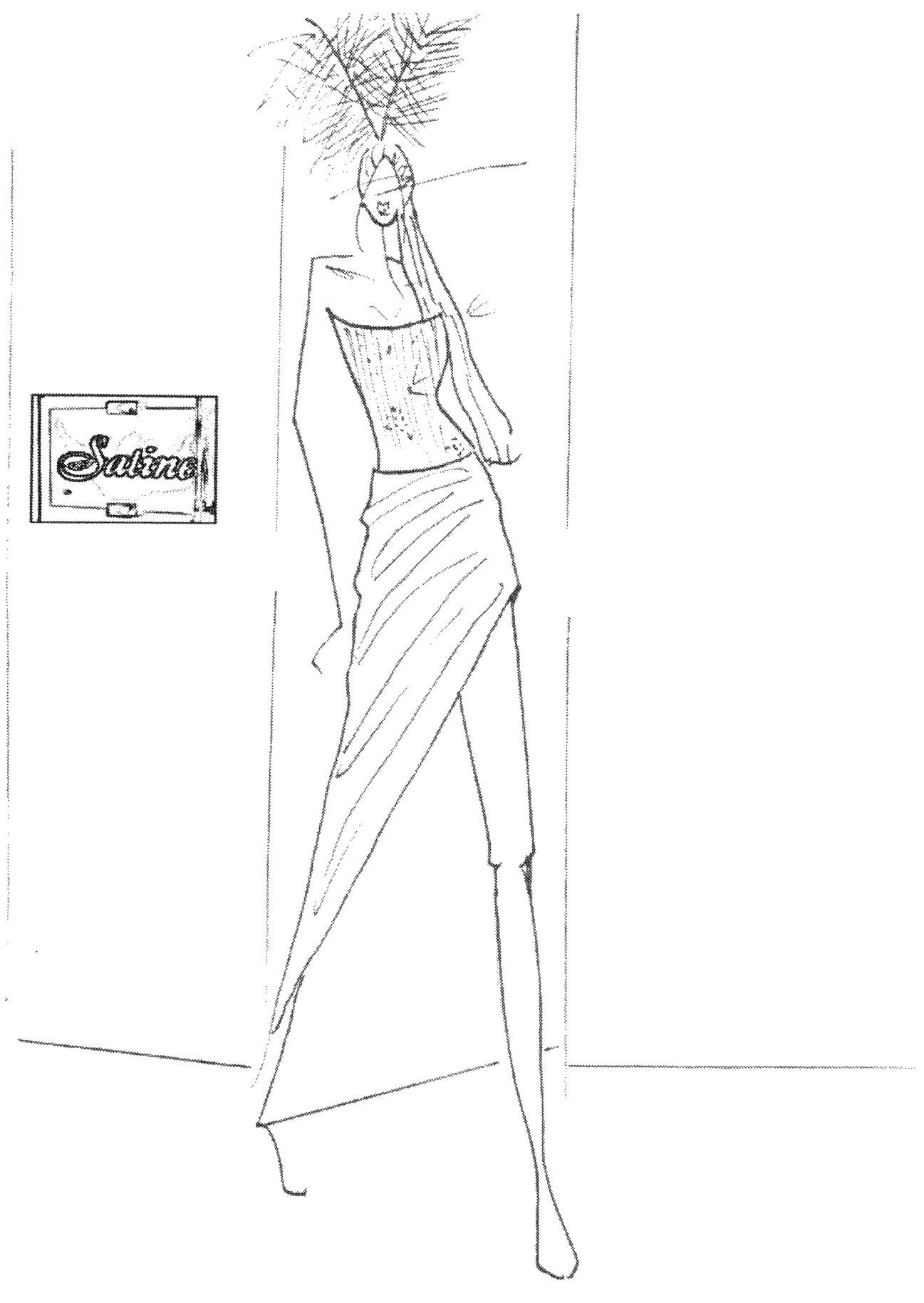


Piel Canela Night

Costumes
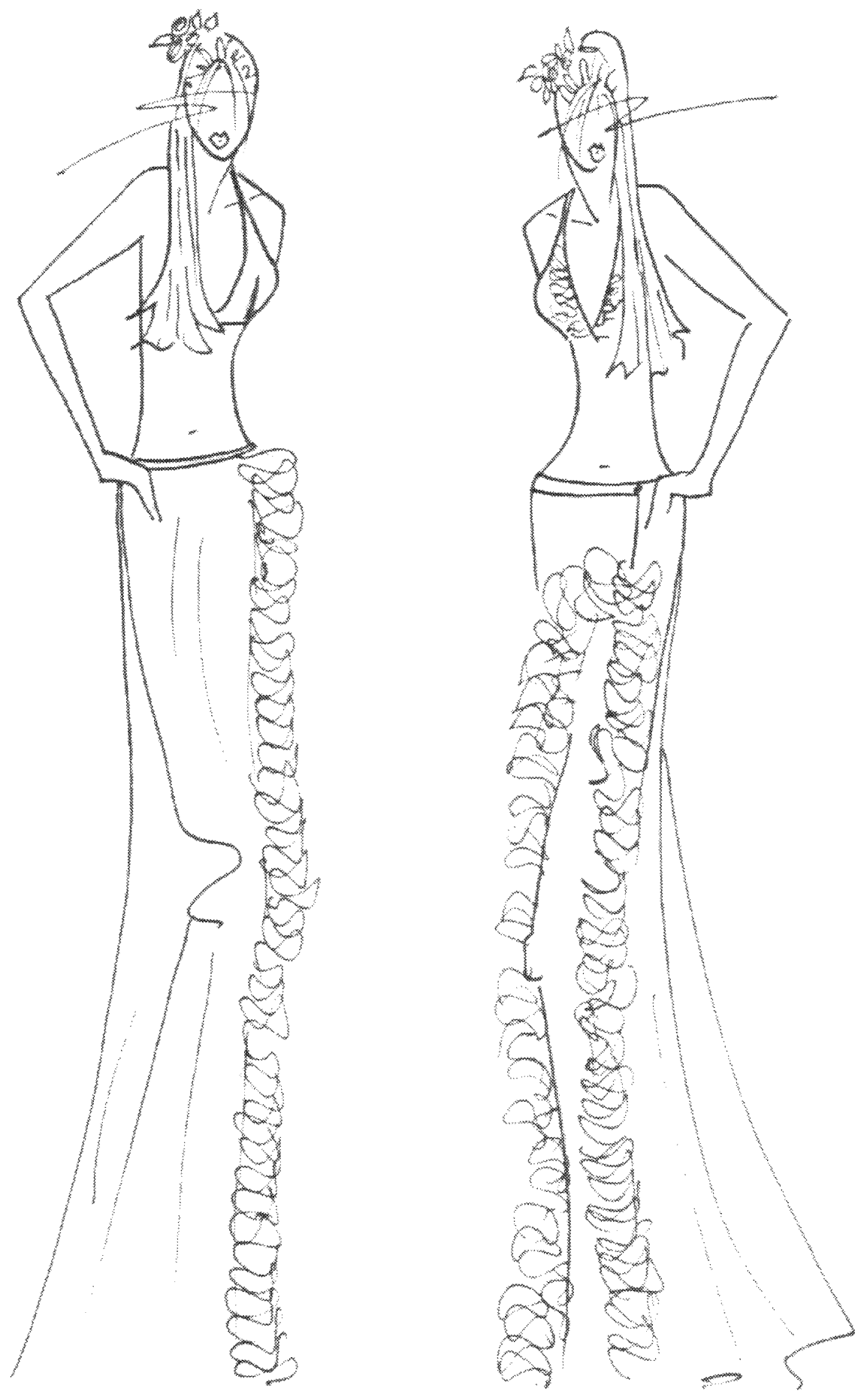
Piel Canela Night

Costumes
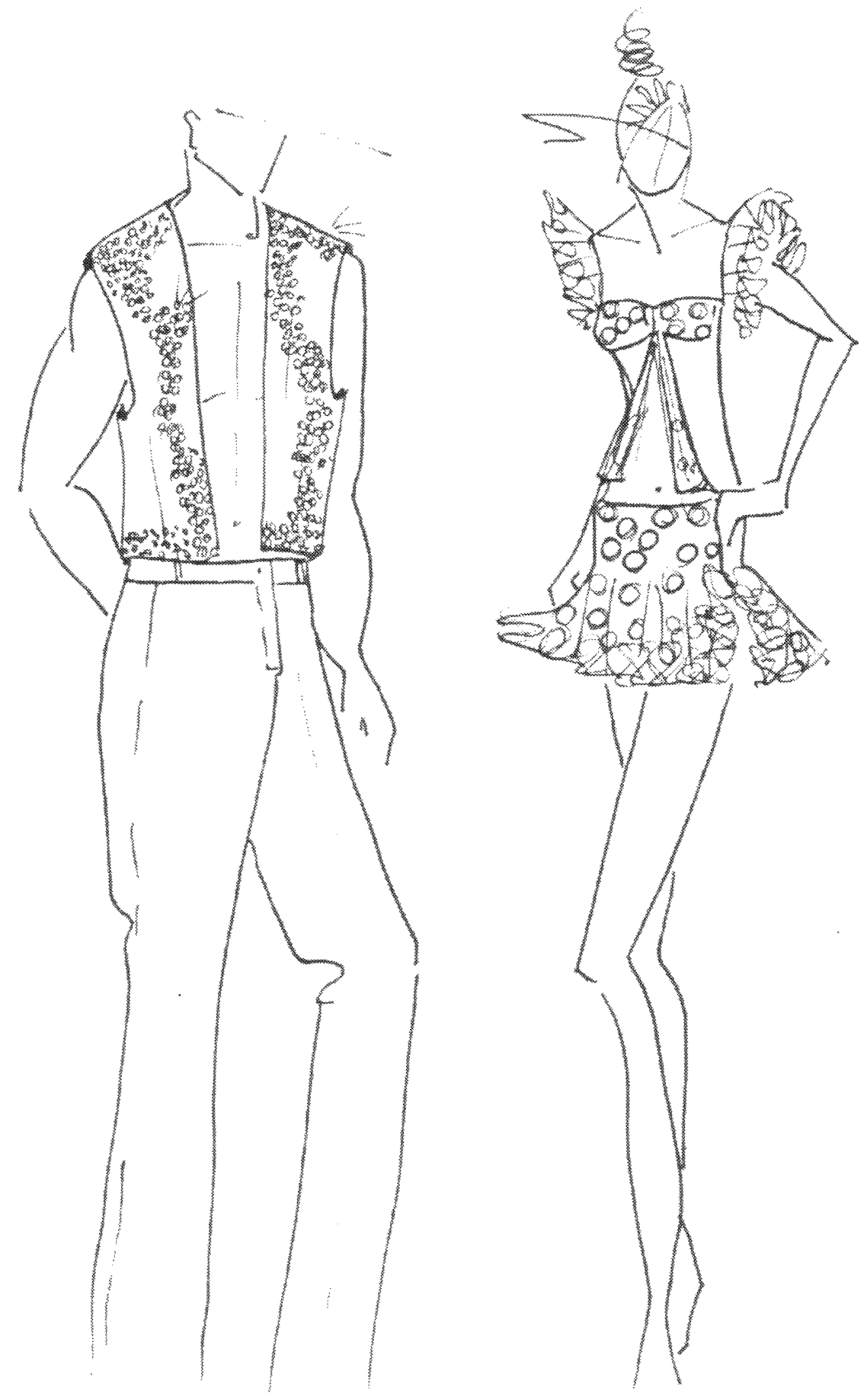
Boss Nova Night Costumes

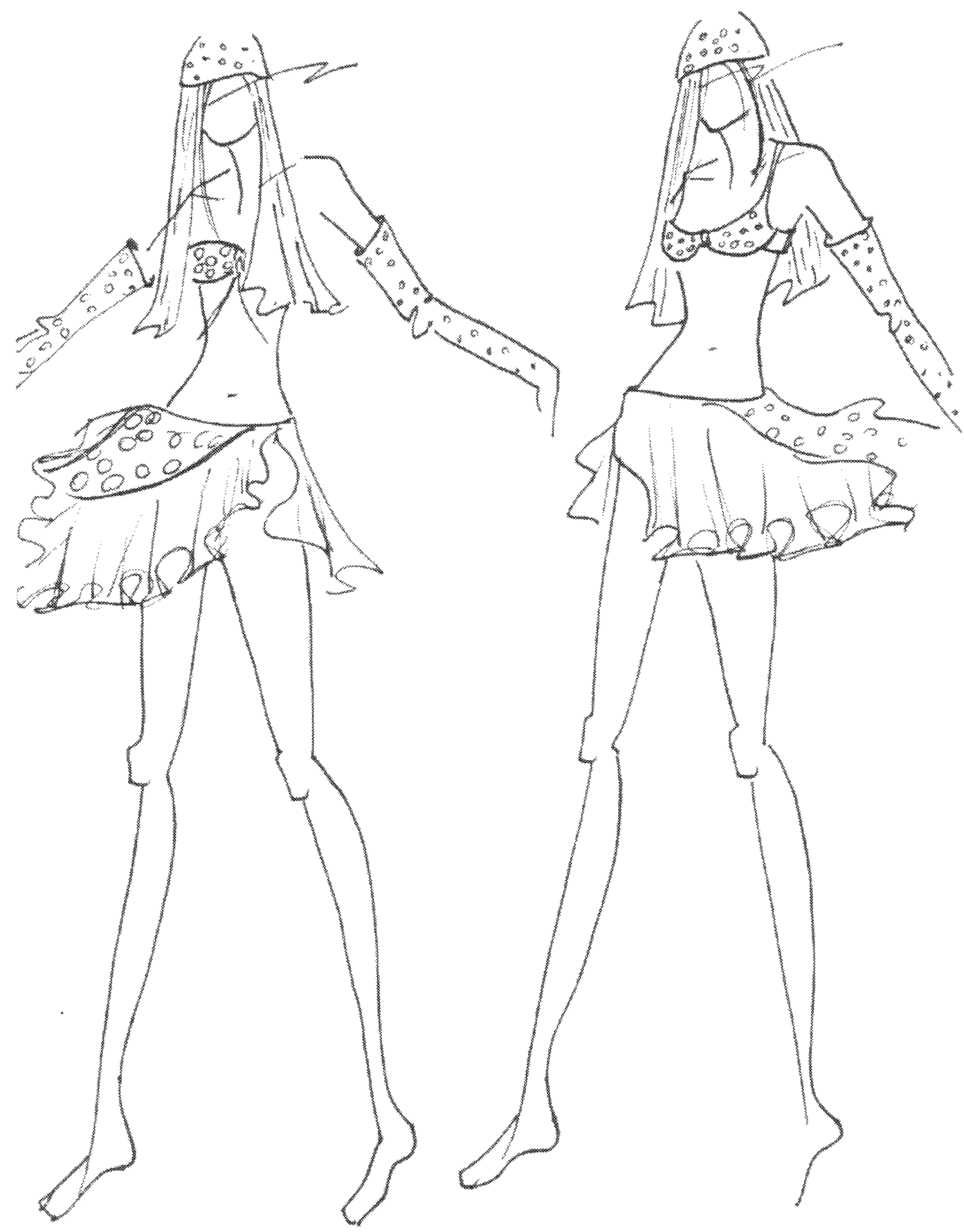

38 
Show:

Scene:

Date:

By:

\begin{tabular}{|l|l|l|l|}
\hline \multicolumn{2}{|l|}{ Dancer: } & Phone: & Character: \\
\hline Height: & Weight: & Ring: & Shoe: \\
\hline Dress: & Skirt: & Blouse: & Bra: \\
\hline
\end{tabular}

\begin{tabular}{|l|l|l|l|}
\hline \multicolumn{2}{|c|}{ Dress } & Girth & \\
\hline Bust & & Thigh & \\
\hline Bust Below & & & \\
\hline Waist & & Knee & \\
\hline Hips & & Calf & \\
\hline & & Ankle & \\
Front Neck to & & & \\
\hline $\begin{array}{l}\text { Baist } \\
\text { Waist Neck to }\end{array}$ & & & \\
\hline Cross Back & & Outseam & \\
\hline & & Inseam & \\
\hline $\begin{array}{l}\text { Skirt Length to } \\
\text { Knee }\end{array}$ & & & \\
\hline $\begin{array}{l}\text { Skirt Length to } \\
\text { Floor }\end{array}$ & & & \\
\hline & & & \\
\hline Sleeve & & Head & \\
\hline Armseye & & Glove & \\
\hline Neck & & & \\
\hline Bicep & & & \\
\hline Elbow & & & \\
\hline Wrist & & & \\
\hline & & & \\
\hline Notes: & & & \\
\hline
\end{tabular}




\section{Show:}

Scene:

Date:

By:

\begin{tabular}{|l|l|l|l|}
\hline Dancer: & Phone: & \\
\hline Height: & Weight: & Ring: & Shoe: \\
\hline Suit: & Shirt: & Pants: & Sweater: \\
\hline
\end{tabular}

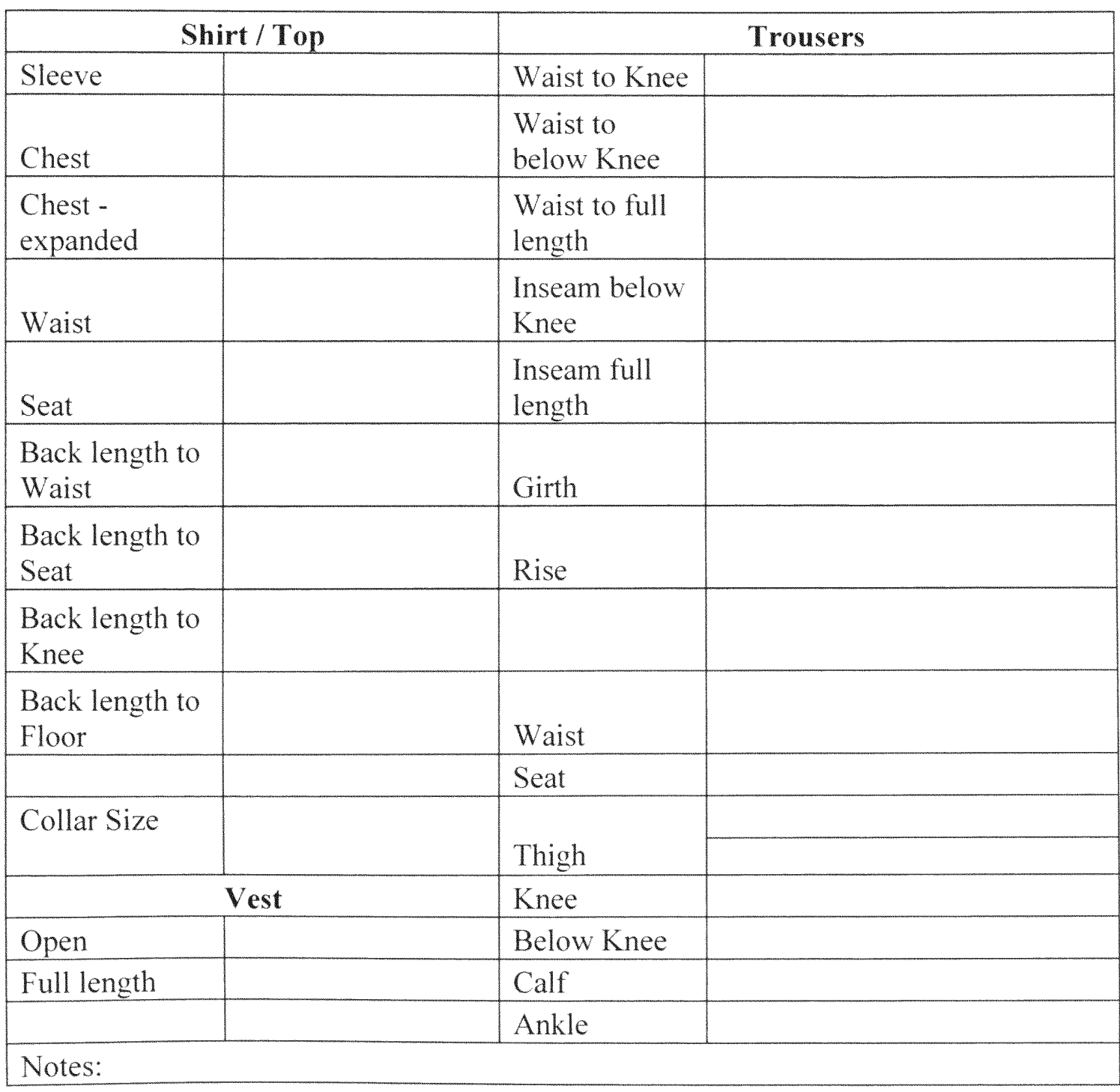




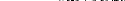




\section{SATINE RESTAURANT \\ ELECTRO TANGO \\ STAGE MANAGER SCENE REPORT}

Show: The Band

Date: Thursday

Schedule Start Time: 8:00pm

End Time: 9:00pm

\section{Set Notes:}

All the props should be set-up 6:00pm, before restaurant opens.

\section{Custom Notes:}

band / all black with Argentinean hats

greeter sexy tanguera custom

\section{Prop Notes:}

Piano, bandoneon, bass and violin

projector

projector stand

3 chairs

2 music stands

\section{Sound \& Light Notes:}

general wash

spot light

\section{Performers / Stage Staff:}

$1 \mathrm{VJ}$ operator

1 spot light operator

1 greeter

1 pianist

1 bandoneon player

1 violinist

1 bass 
ELECTRO TANGO

JAZZ BAND

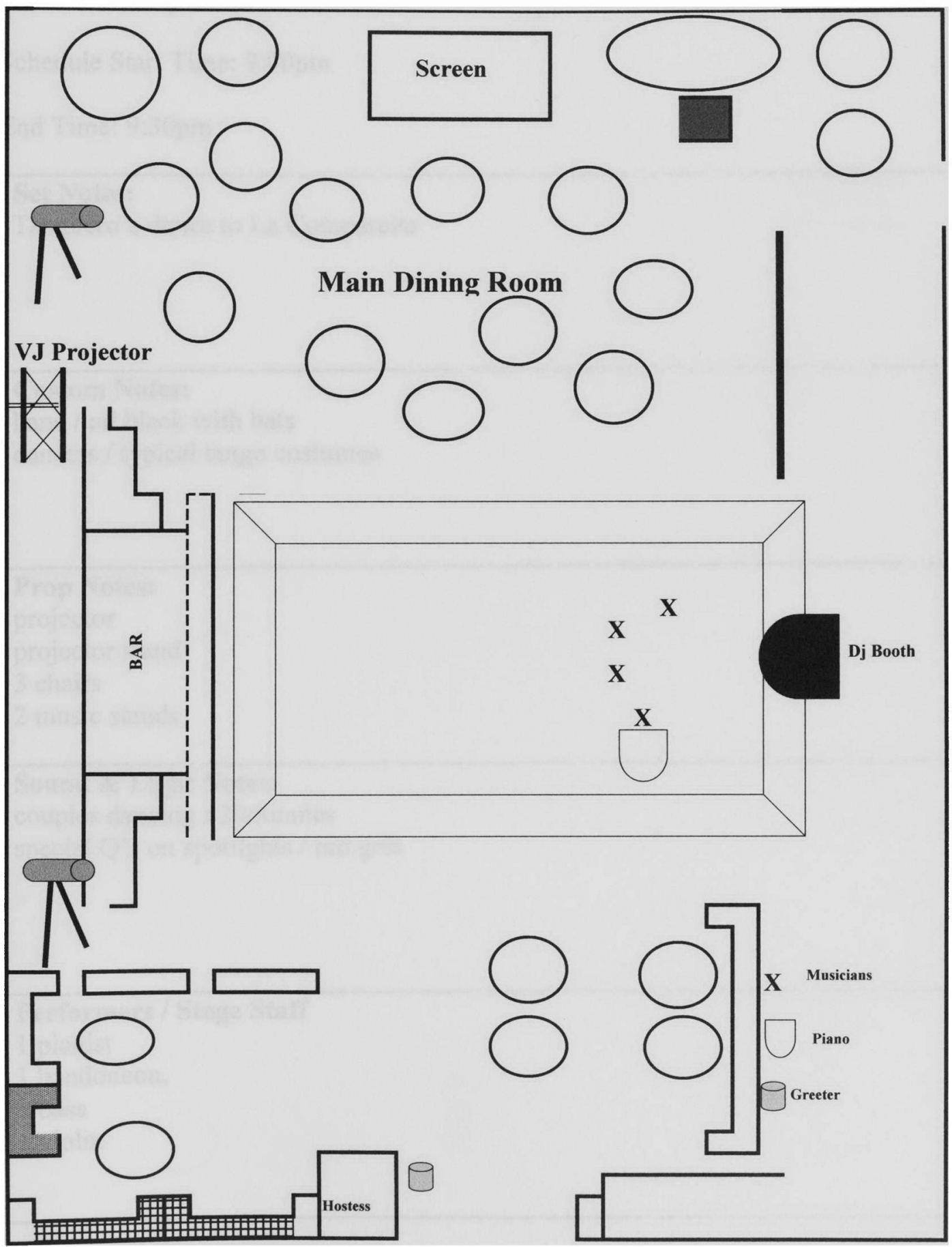

Main Entrance 


\section{SATINE RESTAURANT \\ ELECTRO TANGO \\ STAGE MANAGER SCENE REPORT}

Show: La Comparcita

Date: Thursday

Schedule Start Time: 9:00pm

End Time: 9:30pm

Set Notes:

Tanguero's dance to La Comparcita

Custom Notes:

band / all black with hats

dancers / typical tango costumes

\section{Prop Notes:}

projector

projector stand

3 chairs

2 music stands

Sound \& Light Notes:

couples dancing / 20minutes

special Q's on spotlights / red gels

Performers / Stage Staff

1 pianist

1 bandoneon,

1 bass

1 violin 
ELECTRO TANGO

LA COMPARCITA

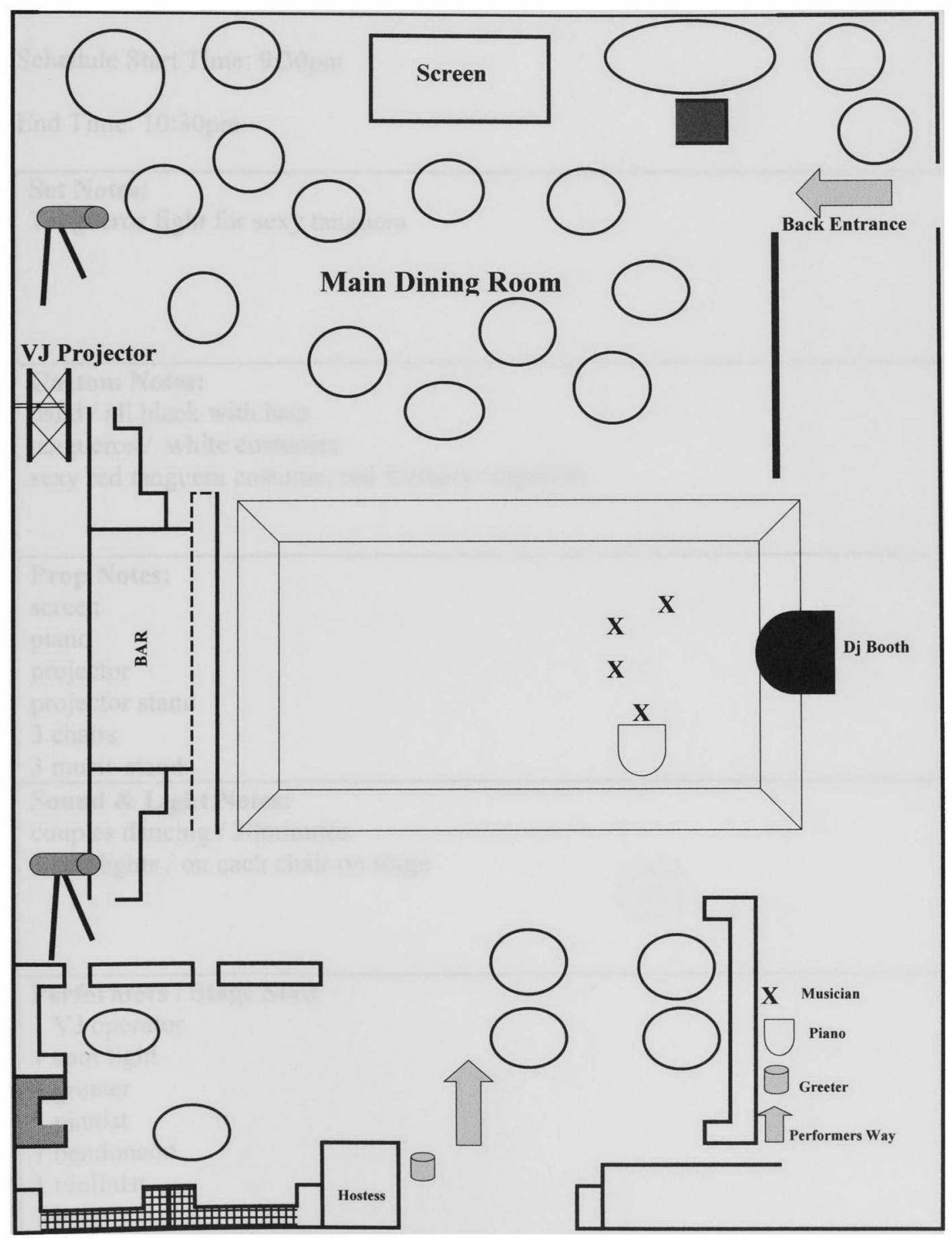

Main Entrance 


\section{SATINE RESTAURANT \\ ELECTRO TANGO \\ STAGE MANAGER SCENE REPORT}

Show: Tango Fight

Date: Thursday

Schedule Start Time: 9:30pm

End Time: $10: 30 \mathrm{pm}$

Set Notes:
Tangueros fight for sexy tanguera

Custom Notes:

band / all black with hats

tangueros / white costumes

sexy red tanguera costume, red feathers / cigarette

\section{Prop Notes:}

screen

piano

projector

projector stand

3 chairs

3 music stands

Sound \& Light Notes:

couples dancing / 30 minutes

3 spotlights / on each chair on stage

\section{Performers / Stage Staff}

1 VJ operator

1 spot light

1 greeter

1 pianist

1 bandoneon

1 violinist

1 bass

1 DJ 


\section{ELECTRO TANGO \\ TANGO FIGHT}

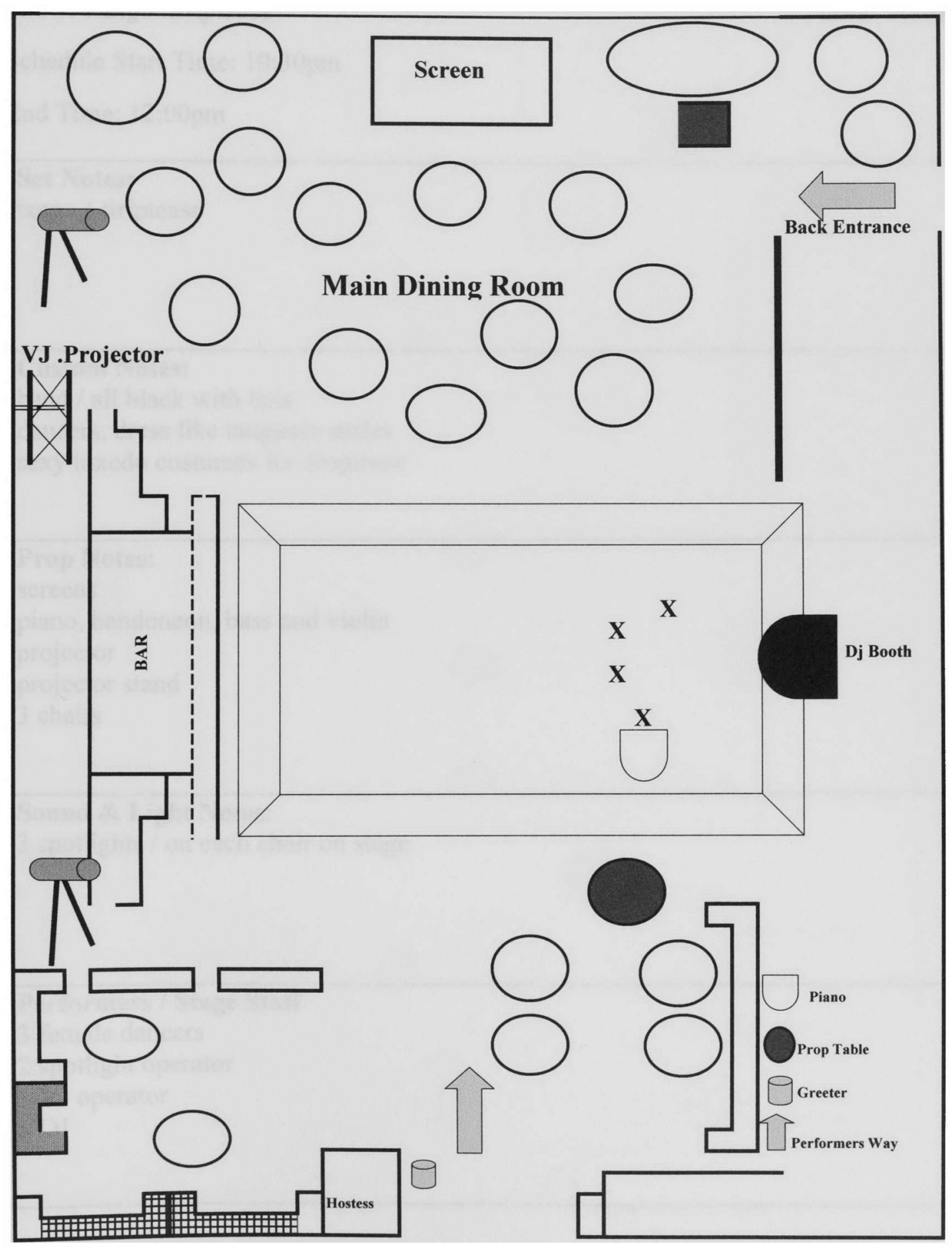

Main Entrance 


\section{SATINE RESTAURANT \\ ELECTRO TANGO \\ STAGE MANAGER SCENE REPORT}

Show: Tango Striptease

Date: Thursday

Schedule Start Time: 10:30pm

End Time: $12: 00 \mathrm{pm}$

\section{Set Notes:}

tango / striptease

\section{Custom Notes:}

band / all black with hats

dancers, dress like tanguero males

sexy tuxedo costumes for striptease

\section{Prop Notes:}

screens

piano, bandoneon, bass and violin

projector

projector stand

3 chairs

\section{Sound \& Light Notes:}

3 spotlights / on each chair on stage

\section{Performers / Stage Staff}

3 female dancers

2 spotlight operator

1 VJ operator

$1 \mathrm{DJ}$ 


\section{ELECTRO TANGO \\ STRIPTEASE}

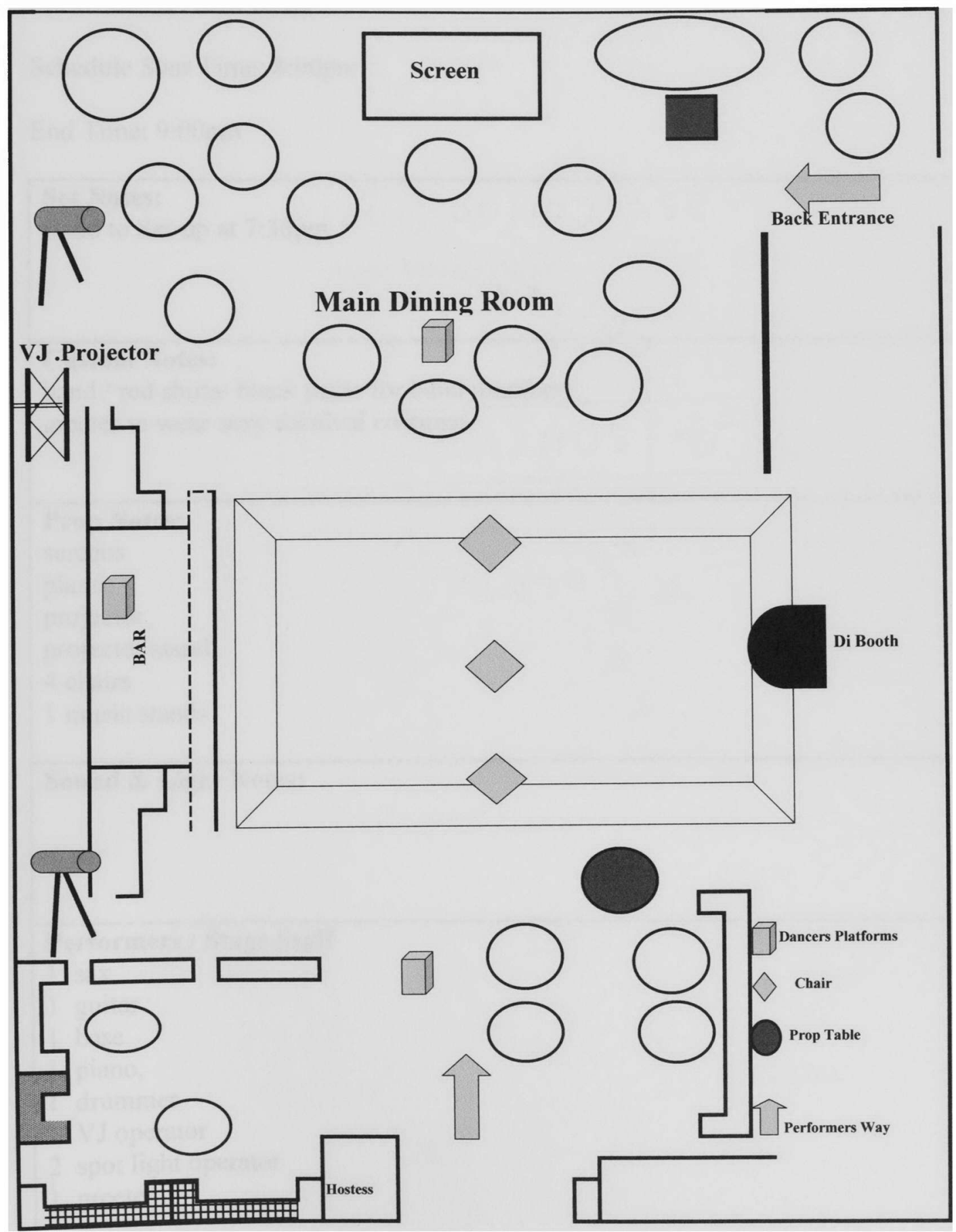

Main Entrance 


\section{SATINE RESTAURANT \\ BOSSA NOVA NIGHT \\ STAGE MANAGER SCENE REPORT}

Show: Bossa Nova Band

Date: Friday

Schedule Start Time: 8:00pm

End Time: 9:00pm

\section{Set Notes:}

Band to Set-up at 7:30pm

\section{Custom Notes:}

band/red shirts/ black pants for band members

greeter to wear sexy carnival costume

\section{Prop Notes:}

screens

piano

projector

projector stand

4 chairs

1 music stands

\section{Sound \& Light Notes:}

\section{Performers / Stage Staff}

1 sax

1 guitar

1 base

1 piano,

1 drummer

$1 \mathrm{VJ}$ operator

2 spot light operator

1 greeter 


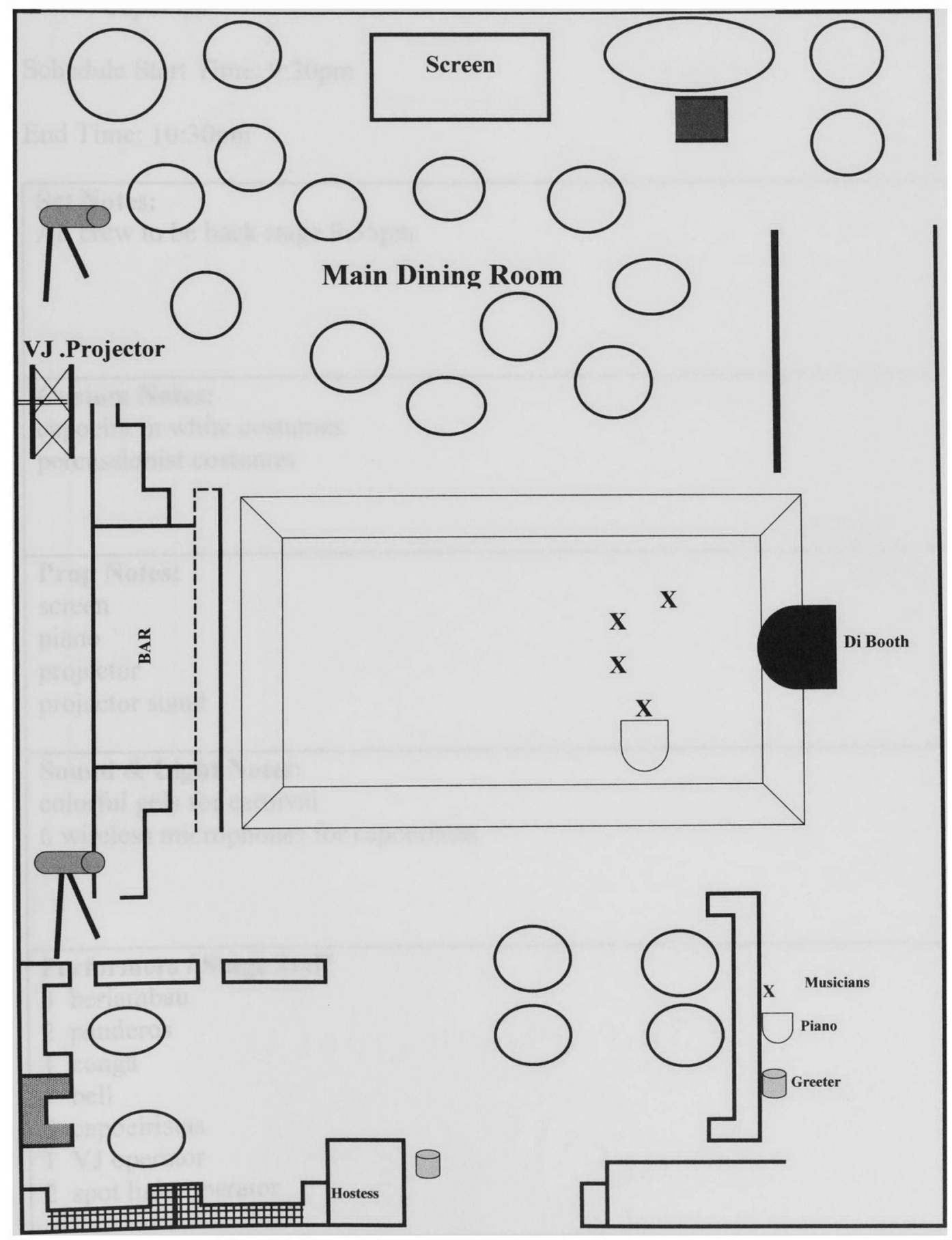

Main Entrance 


\section{SATINE RESTAURANT \\ BOSSA NOVA NIGHT \\ STAGE MANAGER SCENE REPORT}

Show: Capoeira

Date: Friday

Schedule Start Time: 9:30pm

End Time: 10:30pm

\section{Set Notes:}

All crew to be back stage $9: 55 \mathrm{pm}$

\section{Custom Notes:}

capoeira in white costumes

percussionist costumes

\section{Prop Notes:}

screen

piano

projector

projector stand

\section{Sound \& Light Notes:}

colorful gels for carnival

6 wireless microphones for capoeristas

\section{Performers / Stage Staff}

3 beriambau

2 panderos

1 conga

1 bell

6 capoeiristas

1 VJ operator

2 spot light operator 
BOSSA NOVA NIGHT

CAPOEIRA

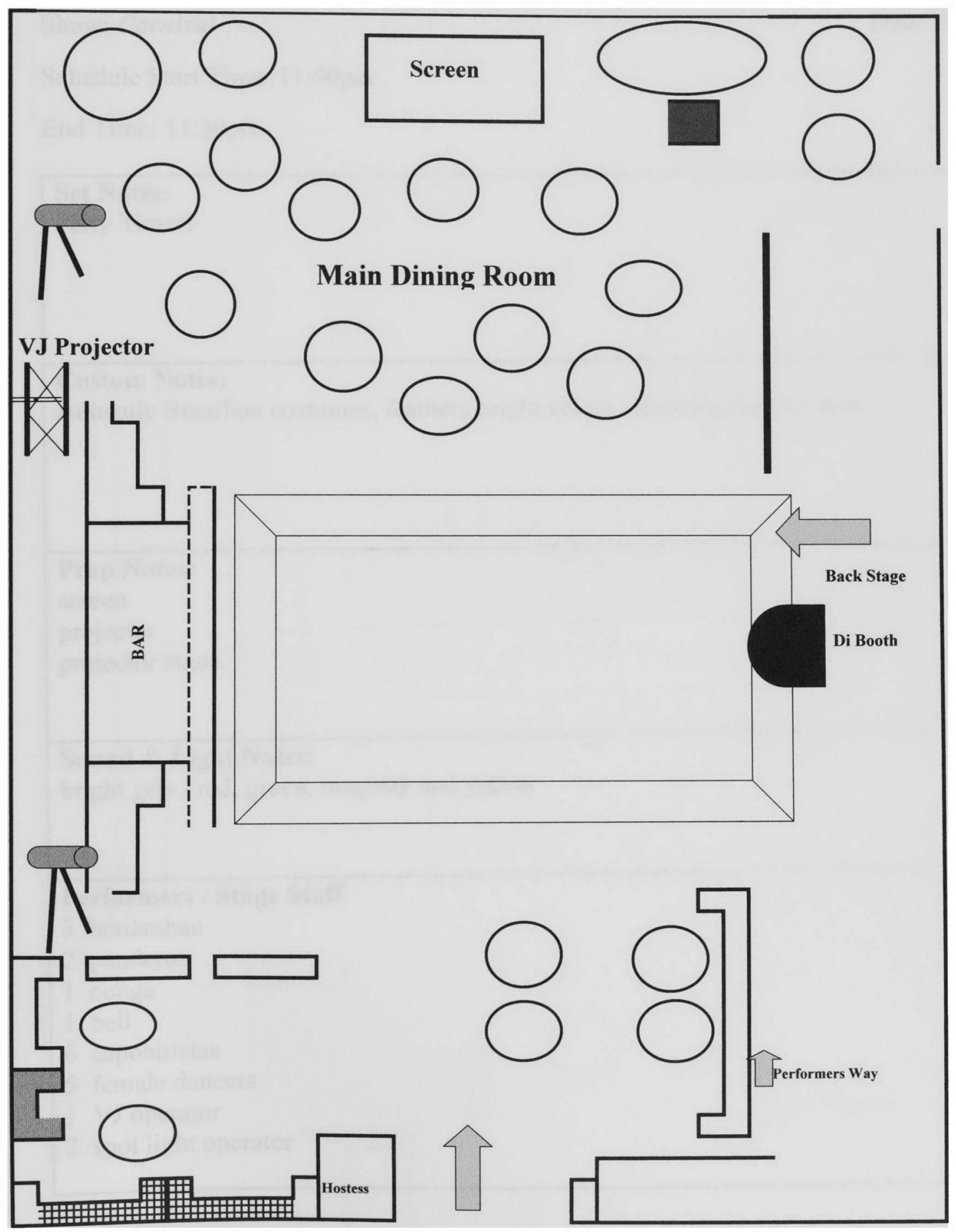

Main Entrance 


\section{SATINE RESTAURANT \\ BOSSA NOVA NIGHT \\ STAGE MANAGER SCENE REPORT}

Show: Carnival

Date: Friday

Schedule Start Time: 11:00pm

End Time: 11:30pm

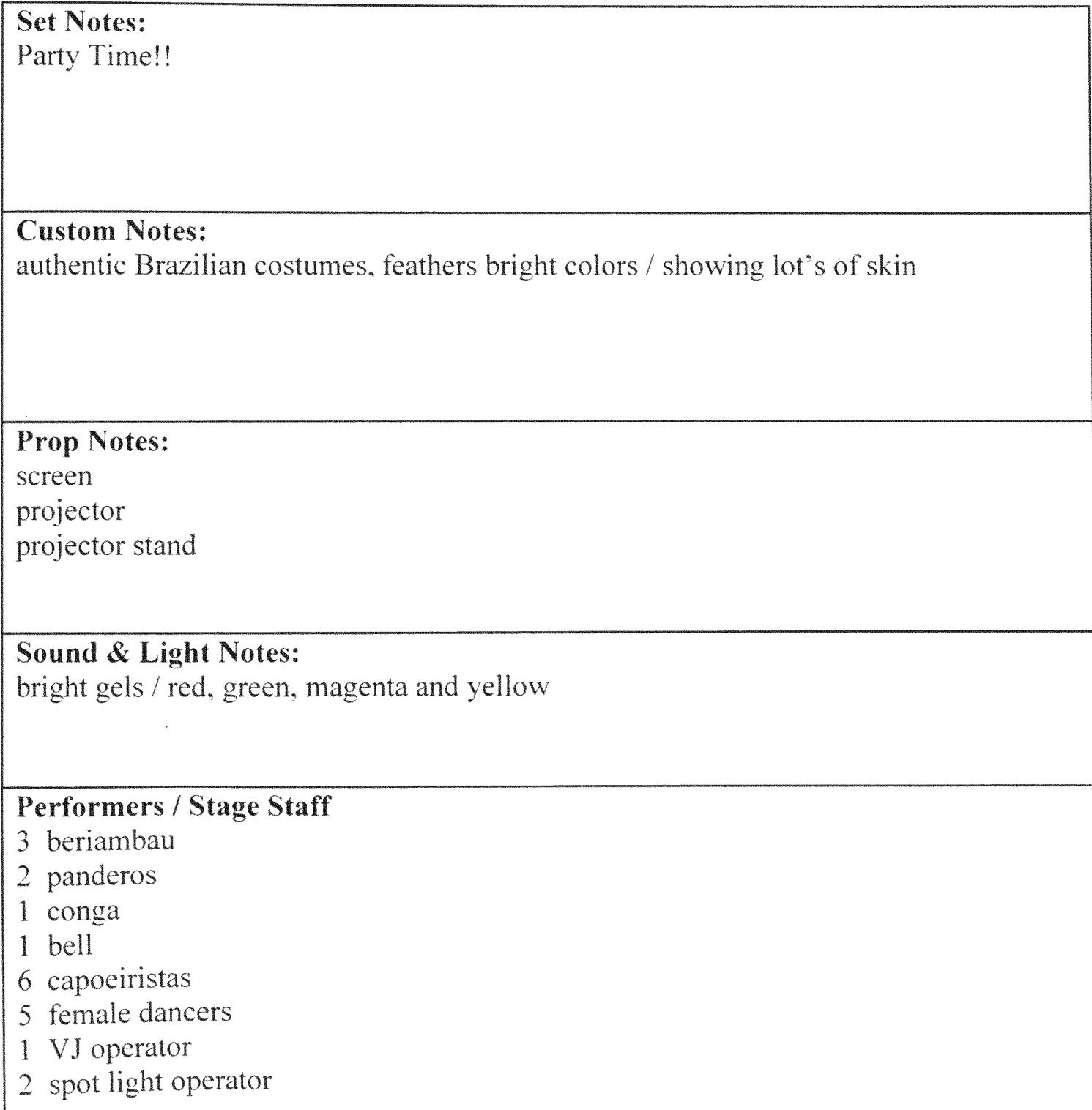


BOSSA NOVA NIGHT

CARNIVAL

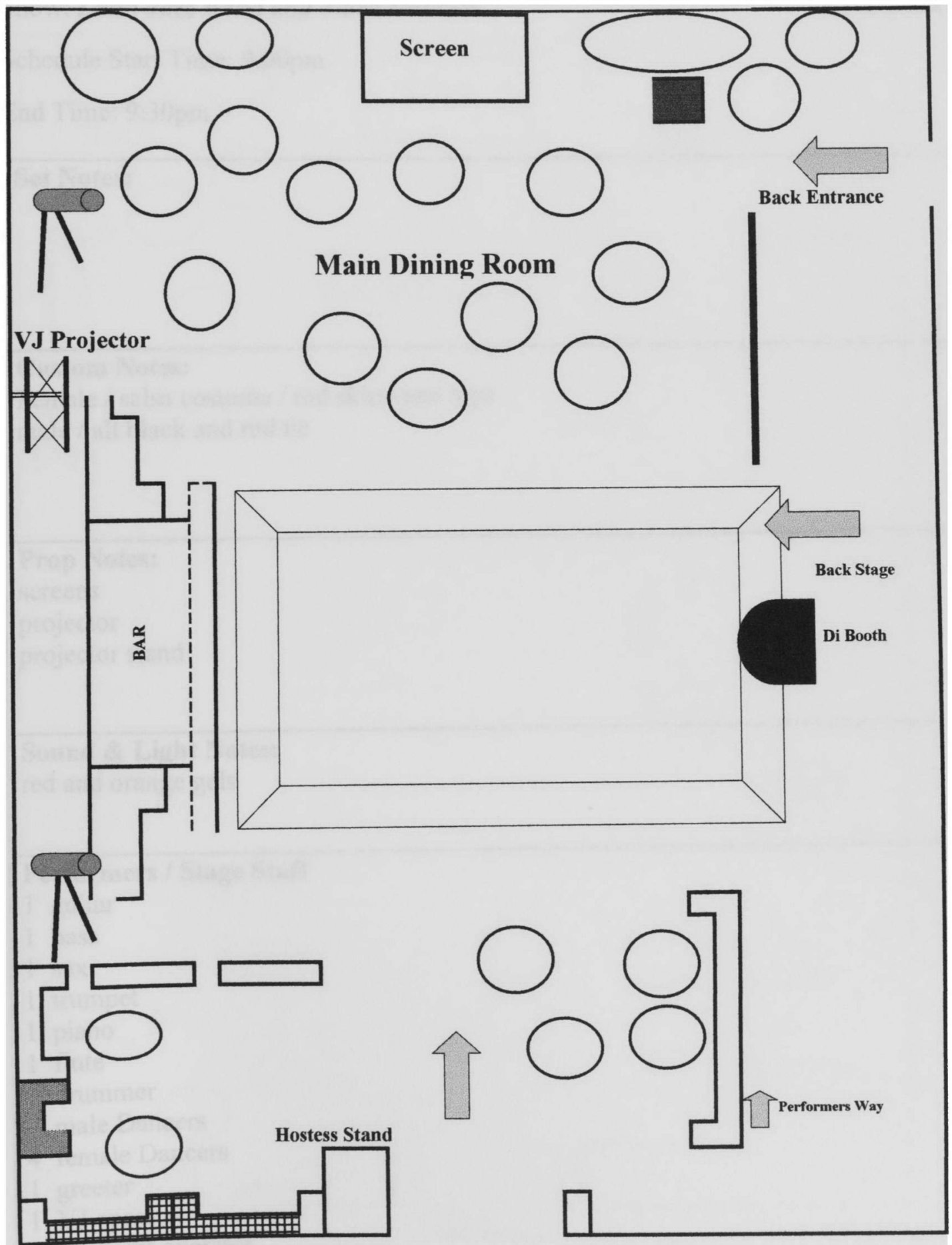

Main Entrance 


\section{SATINE RESTAURANT \\ PIEL CANELA \\ STAGE MANAGER SCENE REPORT}

Show: Latin Jazz Band and Salsa Dancers

Date: Saturday

Schedule Start Time: 9:00pm

End Time: 9:30pm

Set Notes:

\section{Custom Notes:}

Female / salsa costume / red skirts and tops

male / all black and red tie

\section{Prop Notes:}

screens

projector

projector stand

Sound \& Light Notes:

red and orange gels

\section{Performers / Stage Staff}

1 guitar

1 bass

$1 \mathrm{sax}$

1 trumpet

1 piano

1 flute

1 drummer

4 male Dancers

4 female Dancers

1 greeter

1 VJ operator

2 spotlight operator 
PIEL CANELA

LATIN JAZZ BAND

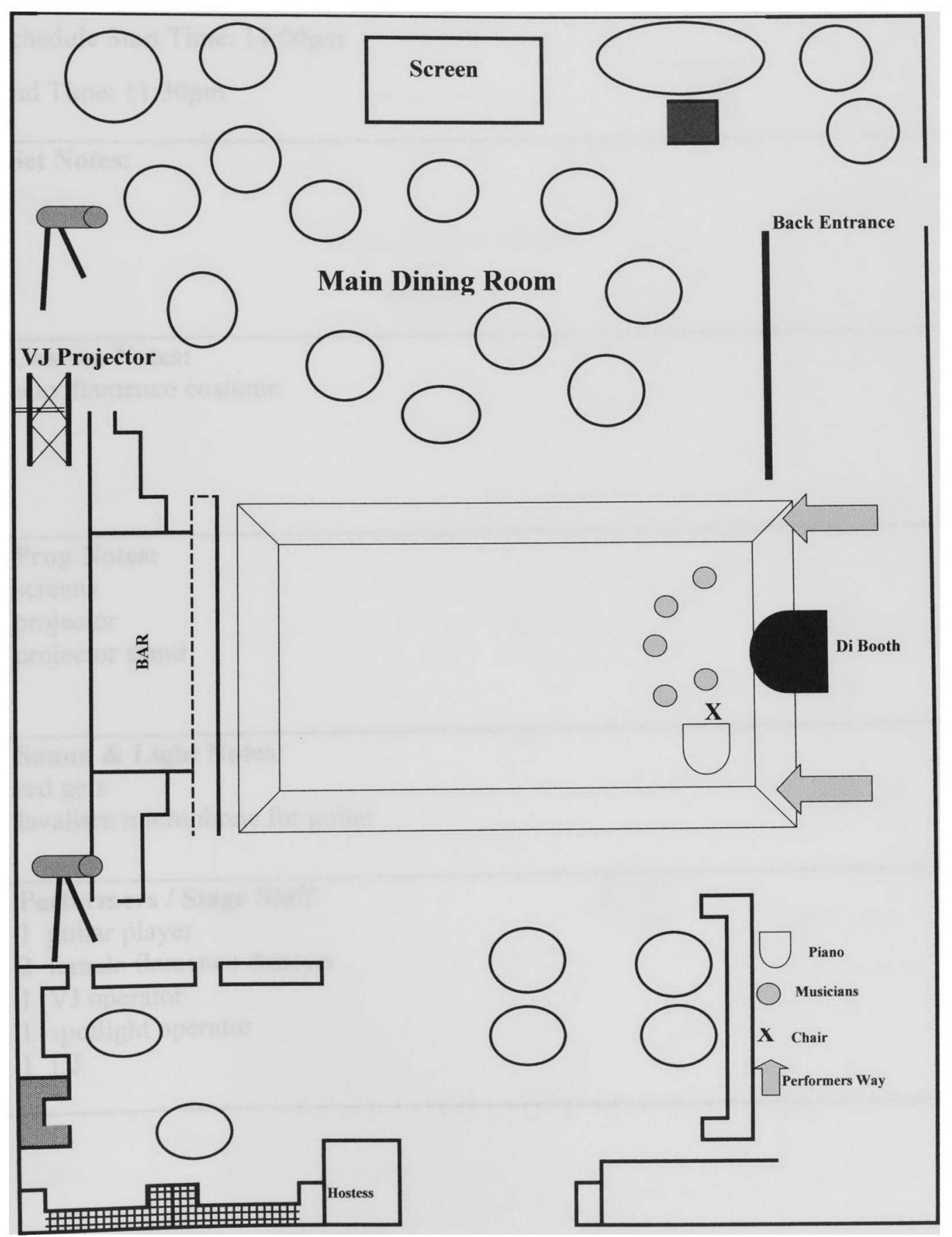

Main Entrance 


\section{SATINE RESTAURANT \\ PIEL CANELA \\ STAGE MANAGER SCENE REPORT}

Show: Flamenco

Date: Friday

Schedule Start Time: 11:00pm

End Time: $11: 30 \mathrm{pm}$

\section{Set Notes:}

Custom Notes:

sexy flamenco costume

Prop Notes:

screens

projector

projector stand

Sound \& Light Notes:

red gels

lavaliere microphone for guitar

Performers / Stage Staff

1 guitar player

2 female flamenco dancers

1 VJ operator

1 spotlight operator

1 DJ 
PIEL CANELA

FLAMENCO

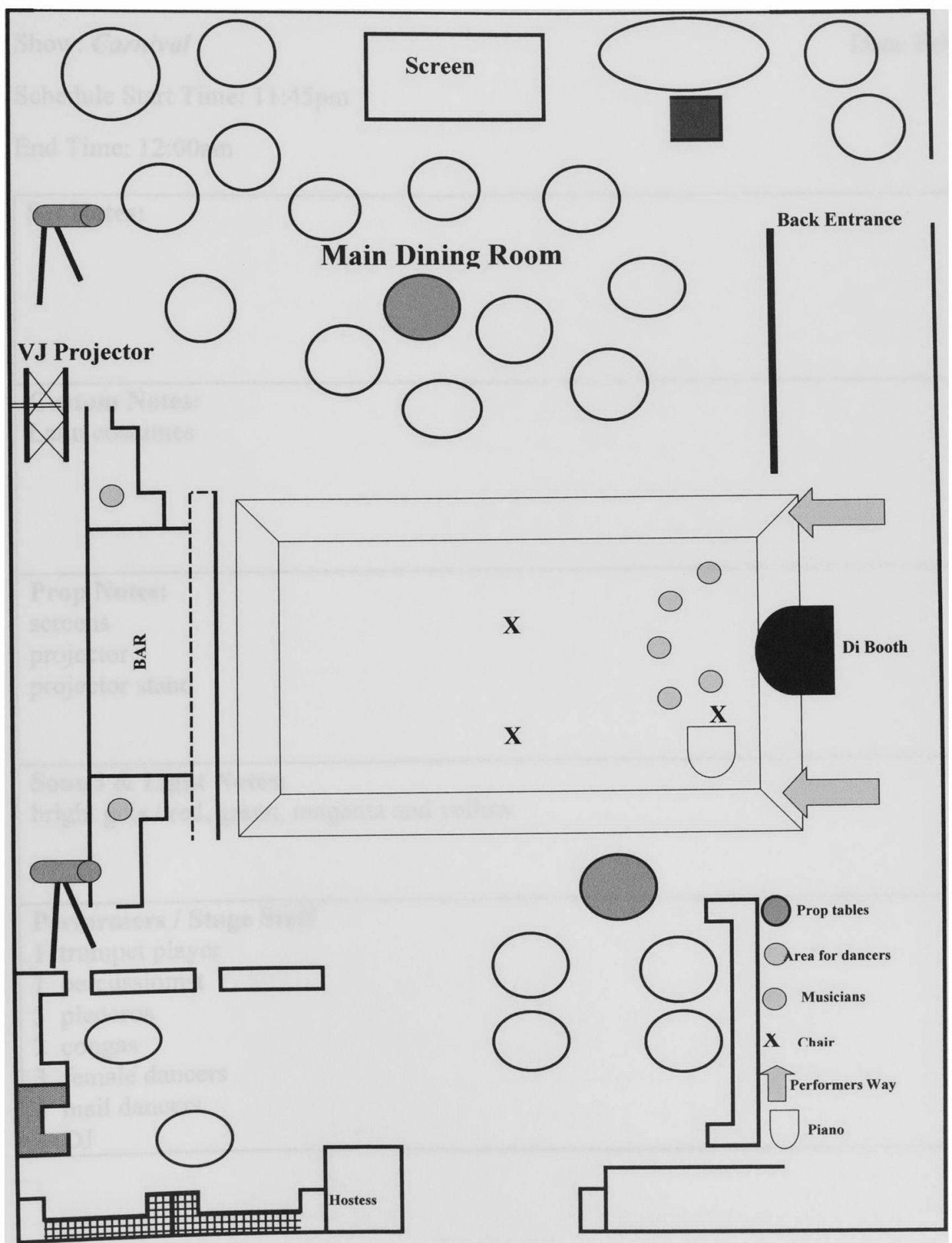

Main Entrance 


\section{SATINE RESTAURANT \\ PIEL CANELA \\ STAGE MANAGER SCENE REPORT}

Show: Carnival

Date: Friday

Schedule Start Time: 11:45pm

End Time: 12:00am

\section{Set Notes:}

Custom Notes:

Latin costumes

Prop Notes:

screens

projector

projector stand

Sound \& Light Notes:

bright gels / red, green, magenta and yellow

\section{Performers / Stage Staff}

1 trumpet player

1 percussionist

3 pleneros

2 congas

3 female dancers

3 mail dancers

1 DJ 
PIEL CANELA

CARNIVAL

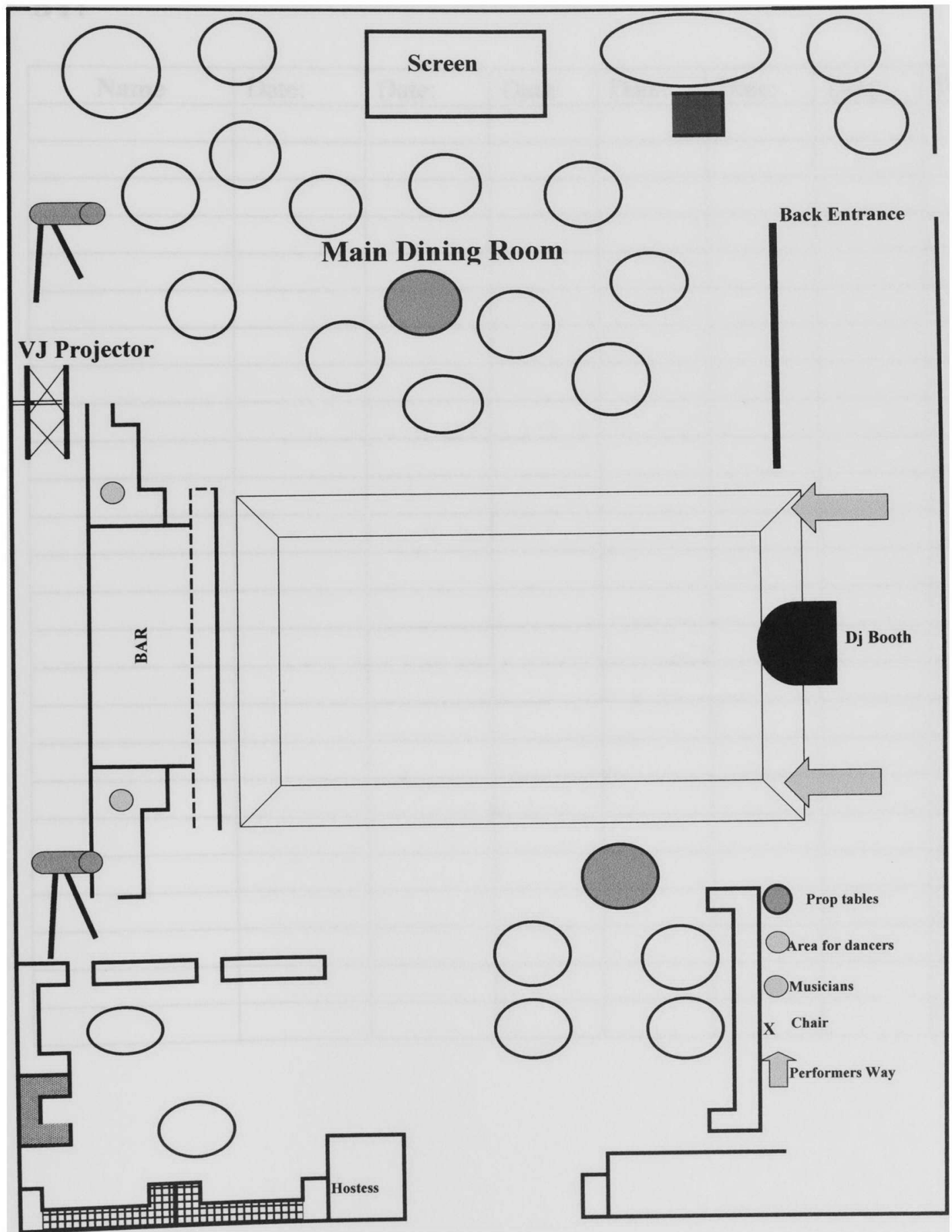

Main Entrance 


\section{CREW SIGN-IN SHEET}

SHOW:

DATE:

BY:

\begin{tabular}{|c|c|c|c|c|c|c|c|}
\hline Name & Date: & Date: & Date: & Date: & Date: & Date: & Date: \\
\hline & & & & & & & \\
\hline & & & & & & & \\
\hline & & & & & & & \\
\hline & & & & & & & \\
\hline & & & & & & & \\
\hline & & & & & & & \\
\hline & & & & & & & \\
\hline & & & & & & & \\
\hline & & & & & & & \\
\hline & & & & & & & \\
\hline & & & & & & & \\
\hline & & & & & & & \\
\hline & & & & & & & \\
\hline & & & & & & & \\
\hline & & & & & & & \\
\hline & & & & & & & \\
\hline & & & & & & & \\
\hline & & & & & & & \\
\hline & & & & & & & \\
\hline & & & & & & & \\
\hline & & & & & & & \\
\hline & & & & & & & \\
\hline & & & & & & & \\
\hline & & & & & & & \\
\hline & & & & & & & \\
\hline
\end{tabular}




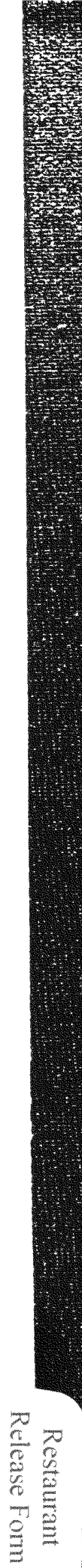




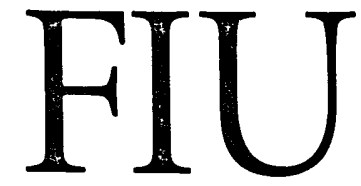

FLORIDA INTERNATIONAL UNIVERSITY

Miami's public research university

\section{RELEASE FORM}

I, Mike Penrod, Owner of Satine Restaurant and Lounge, hereby irrevocably consent to the use of Satine Restaurant and Lounge logo by Cynthia Gredel Berrios and authorize the use of the logo for her thesis project entitled The Design, Implementation and Production Process of Creating a Viable Series of Latin Shows in Hollywood, Florida

I hereby release Cynthia G. Berrios and Florida International University from all claims of every kind on account of such use.

Owner Signature:

Address:

Hollywood, Fe 33019

Telephone:

Today's Date: May 1,2004 